\title{
Co-contamination of water with chlorinated hydrocarbons and heavy metals: challenges and current bioremediation strategies
}

\author{
A. Arjoon · A. O. Olaniran • B. Pillay
}

Received: 11 January 2012/Revised: 28 February 2012/Accepted: 2 August 2012/Published online: 21 November 2012

(c) CEERS, IAU 2012

\begin{abstract}
Chlorinated hydrocarbons can cause serious environmental and human health problems as a result of their bioaccumulation, persistence and toxicity. Improper disposal practices or accidental spills of these compounds have made them common contaminants of soil and groundwater. Bioremediation is a promising technology for remediation of sites contaminated with chlorinated hydrocarbons. However, sites co-contaminated with heavy metal pollutants can be a problem since heavy metals can adversely affect potentially important biodegradation processes of the microorganisms. These effects include extended acclimation periods, reduced biodegradation rates, and failure of target compound biodegradation. Remediation of sites co-contaminated with chlorinated organic compounds and toxic metals is challenging, as the two components often must be treated differently. Recent approaches to increasing biodegradation of organic compounds in the presence of heavy metals include the use of dual bioaugmentation; involving the utilization of heavy metal-resistant bacteria in conjunction with an organicdegrading bacterium. The use of zero-valent irons as a novel reductant, cyclodextrin as a complexing agent, renewable agricultural biosorbents as adsorbents, biosurfactants that act as chelators of the co-contaminants and phytoremediation approaches that utilize plants for the remediation of organic and inorganic compounds have also been reported. This review provides an overview of the problems associated with co-contamination of sites with chlorinated organics and heavy metals, the current strategies being
\end{abstract}

A. Arjoon · A. O. Olaniran $(\bowtie) \cdot$ B. Pillay Discipline of Microbiology, School of Life Sciences, University of KwaZulu-Natal (Westville Campus), Private Bag X54001, Durban 4000, Republic of South Africa e-mail: olanirana@ukzn.ac.za employed to remediate such sites and the challenges involved.

Keywords Bioaugmentation · Biosorbents · Chlorinated compounds - Cyclodextrin · Heavy metals . Zero-valent irons

\section{Introduction}

Chlorine compounds present a huge assembly of environmental pollutants that negatively affect the wellbeing of both humans and wildlife, thus placing chlorine chemistry at the forefront of public health concern (Hileman 1993). A great amount of chlorinated compounds are manufactured annually for a wide range of commercial, agricultural and industrial uses. There are about 15,000 chlorinated compounds being used in industry, including; pesticides, pharmaceuticals, drinking water disinfectants and many modern consumer products which contain polyvinyl chloride thereby improving the quality of life in both developed and developing countries. In addition, about 1,500-2,000 chlorine compounds are released into the environment from natural sources (Gribble 1996). Chlorinated organic compounds are known to be persistent and thus able to reach high concentrations both in the environment and in human tissues due to their inert nature with regard to biotic and abiotic transformation reactions (Hocheolsong and Carraway 2005). Furthermore, their interactions with hormonal systems have received escalating interest as they are known to be predominantly harmful to the developing embryo, fetus and toddler as well as cause cancer in experimental animals (Hanberg 1996; Hocheolsong and Carraway 2005).

A broad range of chlorinated aliphatic compounds are susceptible to biodegradation under a variety of physiological 
and redox conditions. Microbial biodegradation of these chlorinated aliphatic compounds has been shown to occur under five different physiological conditions; however, any given physiological condition could only act upon a subset of the chlorinated compounds (Field and Sierra-Alvarez 2004). Firstly, chlorinated compounds are used as an electron donor and carbon source under aerobic conditions. Secondly, they are co-metabolized under aerobic conditions while the microorganisms are growing (or otherwise already have grown) on another primary substrate. Thirdly, they are also degraded under these anaerobic conditions in which they are utilized as an electron donor and carbon source. Fourthly, they can serve as an electron acceptor to support respiration of anaerobic microorganisms utilizing simple electrondonating substrates and lastly chlorinated compounds are subject to anaerobic co-metabolism, thereby becoming bio-transformed while the microorganisms grow on other primary substrate or electron acceptor (Field and SierraAlvarez 2004).

Although bioremediation is a promising technology, remediation of sites co-contaminated with organic and metal pollutants is an intricate predicament, as both components must be treated differently. Furthermore, it is eminent that the occurrence of heavy metals can reduce a broad range of microbial processes including metabolism, growth, and the aerobic biodegradation of a range of organic pollutants (Said and Lewis 1991; Sandrin and Maier 2003). Heavy metal pollution from both natural and anthropogenic sources results in the accumulation of metals in ecological niches (Kuo and Genthner 1996). The rate of influx of these heavy metals into the atmosphere far exceeds their elimination by natural processes, consequently leading to the accumulation of heavy metals in the environment, with aquatic ecosystems normally at the receiving end (Shirdam et al. 2006). This review therefore focuses on the effects of heavy metals on the biodegradation of organic pollutants, particularly chlorinated hydrocarbons and the remediation strategies currently being employed to alleviate this problem.

\section{Metal toxicity to microbes}

In nature, living organisms come into contact with heavy metals, frequently existing in their ionized species. All metals, in spite of whether they are essential or non-essential, can exhibit toxic effects at elevated concentrations (Silver 1996). Toxicity of metals to an organism can be defined as the intrinsic potential or ability of a metal to cause negative effects on living organisms and depends on the bioavailability of the metals (Rasmussen et al. 2000). Metals in the environment can be separated into two groups: bioavailable (soluble, nonsorbed and mobile) and non-bioavailable (precipitated, complexed, sorbed and non-mobile). It is the bioavailable metal concentration that is taken up and is toxic to biological systems by exerting diverse toxic effects on microorganisms (Cervantes et al. 2006). In co-contaminated sites, metal toxicity inhibits the processes of organicdegrading microorganisms (Roane et al. 2001). Numerous metal ions can simultaneously cause toxicity on biological systems by more than one biochemical pathways. These reactions can be separated into five mechanistic categories of which the first entails substitutive metal-ligand binding, in which one metal ion replaces another at the binding site of a specific biomolecule, thereby altering or destroying the biological function of the target molecule (Nieboer et al. 1996). Second is the covalent and ionic reduction-oxidation (redox) reaction of metal ions with cellular thiols (R-SH) (Stohs and Bagchi 1995; Zannoni et al. 2007), in particular, glutathione (Turner et al. 2001). Studies have shown that metals, including iron, copper, chromium, and vanadium undergo redox cycling, while cadmium, mercury, and nickel, as well as lead, deplete glutathione and protein-bound sulfhydryl groups $(-\mathrm{SH})$, resulting in the production of reactive oxygen species (ROS) as superoxide ions, hydrogen peroxide, and hydroxyl radicals and as a consequence, enhanced lipid peroxidation, DNA damage, and altered calcium and sulfhydryl homeostasis occur. Fenton-like reactions may be commonly associated with most membranous fractions including mitochondria, microsomes, and peroxisomes. The third category involves the participation of transition metals, such as $\mathrm{Cu}, \mathrm{Ni}$ and $\mathrm{Fe}$, in Fenton-type reactions that produce ROS, such as $\mathrm{H}_{2} \mathrm{O}_{2}$, hydroxyl radicals $\left(\mathrm{OH}^{-}\right)$and $\mathrm{O}_{2}{ }^{-}$(Stohs and Bagchi 1995; Inoaoka et al. 1999; Geslin et al. 2001). In general, ROS are transient and highly reactive compounds that can damage all biological macromolecules (Pomposiello and Demple 2002). The fourth category entails interference with membrane transport processes, in which a toxic metal species can competitively inhibit a specific membrane transporter by occupying binding sites or by using and/or interfering with the membrane potential that is normally reserved for an essential substrate (Foulkes 1998). The fifth category involves the indirect siphoning of electrons from the respiratory chain by thiol-disulphide oxidoreductases (Borsetti et al. 2007) thereby destroying the proton motive force of the cell membrane (Lohmeier-Vogel et al. 2004).

\section{Microbial resistance to heavy metals}

Even though metals are known to incapacitate microorganisms that biodegrade organic pollutants, a number of microbial metal-resistance mechanisms are recognized (Roane et al. 2001). In an endeavor to safeguard susceptible cellular components, a cell can build up resistance to metals. Metal containing environments have built up selective 
pressures which eventually lead to the expression of resistance mechanisms to practically all heavy metals (Rouch et al. 1995). Numerous mechanisms by which microorganisms resist metal toxicity exist, and five mechanisms have been hypothesized (Bruins et al. 2000). These include: (1) active or dynamic transport, (2) development of a permeability barrier, (3) enzymatic detoxification (4) reduction in sensitivity, and (5) sequestration (Bruins et al. 2000). Microbes may either use one or more of these methods to eliminate non-essential metals and normalize concentrations of vital metals.

\section{Active or dynamic transport}

In active or dynamic transport, metals are exported away from the microorganism or more specifically from the microorganism's cytoplasm. These mechanisms can be chromosomal or plasmid-encoded while efflux systems can be non-ATPase or ATPase-linked and extremely precise for the cation or anion they export (Bruins et al. 2000). An active transport or efflux mechanism embody the principal category of metal resistance systems and is the most well studied metal resistance system. Three main detoxification mechanisms are known to function in bacteria: (1) $\mathrm{P}_{1 \mathrm{~B}}$-type ATPases, which use ATP energy to pump metals out of the cytoplasm to the periplasm (2) CBA transporters (threecomponent transenvelope pumps, consisting of subunits $\mathrm{C}$, $\mathrm{B}$, and $\mathrm{A}$ ), which extrude metals from the cytoplasm to the periplasm to outside the outer membrane (Franke et al. 2003); and (3) cation diffusion facilitator (CDF) family transporters which function as chemiosmotic ion-proton exchangers (Grass et al. 2001). P-type ATPases and CDF transporters can functionally replace each other, however, they cannot replace CBA transporter (Scherer and Nies 2009). Examples of active transport include the ars operon used in the export of arsenic from E. coli, cop operon for the removal of excess copper from Enterococcus hirae and the cad system for removing cadmium from Staphylococcus aureus (Silver and Phung 1996; Tsutomu and Kobayashi 1998). Ralstonia sp. CH34 encompasses resistance determinants that can detoxify heavy metal ions by inducible ion efflux systems that reduce the intracellular concentration of a given ion by active export (Nies 2000).

\section{Development of a permeability barrier}

For microbes that lack a specific active transport system, metal exclusion by a permeability barrier can be an alternative mechanism whereby the essential cellular components which are metal sensitive are protected by altering the cell wall, membrane or envelope of the microorganism (Bruins et al. 2000). Examples of such alterations include; prevention of entry of heavy metals by diminishing production of membrane channel proteins (Rouch et al. 1995), possible saturation of metal-binding sites in the membrane and periplasm with non-toxic metals (Mergeay 1991), prevention of metals from reaching the surface of the cell by the formation and binding of an extracellular polysaccharide coat (Scott and Palmer 1990). Gram-negative bacteria possess a cell wall that is a more effective barrier to heavy metals than Gram-positive bacteria, as demonstrated by Balestrazzi et al. (2009) that tetra-resistant bacterial isolates were more frequent among the Gram-negative bacteria belonging to the genus Pseudomonas.

Enzymatic detoxification

In microbes without a permeability barrier, enzyme detoxification of the metal to a less toxic form can also be a method to reduce heavy metal toxicity. In contrast to thermophilic or psychrophilic organisms, heavy metalresistant bacteria do not supply enzymes that are active under harsh conditions, but are themselves tools for the evaluation and remediation of heavy metal-contaminated environments (Nies 2000). Several bacteria enclose a metal resistance operon, i.e. a set of genes that can not only detoxify the heavy metal but can transport and self-regulate resistance (Misra 1992; Ji and Silver 1995). The mercury resistance system is the most renowned example of enzyme detoxification. Bacteria that possess the mer operon include E. coli, Thiobacillus ferrooxidans, S. aureus, Pseudomonas aeruginosa, Bacillus sp. and Serratia marcescens. Two different metal resistance mechanisms are encoded by the mer operon, mercury reductase encoded by merA, which allows MerA to follow an enzyme detoxification method because it encodes mercury reductase, where the merAencoded mercuric reductase reduces $\mathrm{Hg}^{2+}$ to the volatile, more stable and less toxic elemental $\mathrm{Hg}^{0}$ (Barkay et al. 2003). Other genes allow for active transport of elemental mercury out of the cells by membrane proteins which are encoded in the operon (Misra 1992; Wireman et al. 1997; Rasmussen et al. 2000). Other examples include the $\mathrm{As}^{3+} \rightarrow \mathrm{As}^{5+}$ oxidase and the $\mathrm{Cr}^{6+} \rightarrow \mathrm{Cr}^{3+}$ reductase. In other cases, such as $\mathrm{As}^{5+}, \mathrm{Ag}^{+}$and $\mathrm{Cd}^{2+}$, no change in redox state occurs but, rather, uptake and transport differences accompany resistance determinants (Jeffrey and Silver 1984). Sulfate-reducing bacteria such as Desulfovibrio vulgaris strain Hildenborough are able to reduce heavy metals by a chemical reduction via the production of $\mathrm{H}_{2} \mathrm{~S}$ and by a direct enzymatic process involving hydrogenases and c3 cytochromes (Goulhen et al. 2006).

Reduction in sensitivity

A fourth mechanism of resistance is the reduction in metal sensitivity whereby some degree of natural protection from 
heavy metal toxicity can be provided to the microorganism by reducing the metal sensitivity of cellular targets. Microorganisms can do this by altering the sensitivity of essential cellular components, thus allowing for adaptation to the presence of heavy metals (Bruins et al. 2000).

\section{Sequestration}

Microbes that lack enzyme protection may be capable of sequestering heavy metals either inside or outside the cell. Intracellular sequestration of metals by protein binding, leads to the accumulation of metals within the cytoplasm thus averting contact to vital cellular components. Metals generally sequestered are $\mathrm{Cd}(\mathrm{II}), \mathrm{Cu}(\mathrm{II})$, and $\mathrm{Zn}(\mathrm{II})$. The two most widespread molecules used for intracellular sequestration are metallothioneins and cysteine-rich proteins (Rouch et al. 1995; Silver and Phung 1996). Alcaligenes eutrophus $\mathrm{CH} 34$ strains internally sequester metals by forming carbonate precipitates within the cell or extra sequestration outside the cell where heavy metals bind to outer cell membrane proteins (Mahvi and Diels 2004). Resistance to extracellular sequestration occurs once the toxic metal is bound in a complex and cannot go through the cell membrane. Examples of molecules used for extracellular sequestration are glutathione and ionic phosphate, which is the foundation for metals to form insoluble complexes (McEntee et al. 1986). Sequestration is also a detoxification mechanism for $\mathrm{Pb}^{2+}$. For example Vibrio harveyi can bind $\mathrm{Pb}^{2+}$ intra- and extracellularly, this avoids toxicity by lowering the concentration of free lead ions by precipitating lead as a phosphate salt.

A comparison of heavy metal resistance systems by Nies (2003) shows that it is the result of multiple layers of resistance systems with overlapping substrate specificities, but unique functions. Some microbial systems of metal tolerance have the potential to be used in biotechnological processes, such as the bioremediation of environmental metal pollution (Cervantes et al. 2006). Even with all of these mechanisms in place for metal resistance, microbes are still susceptible to heavy metals at high concentrations.

\section{Effect of heavy metals on bioremediation process}

In the environment, heavy metal toxicity affects many important microbial processes, including litter decomposition, methanogenesis, acidogenesis, nitrogen transformation, and biodegradation of organics (Baath 1989). Human health and wildlife are becoming increasingly compromised due to the various organic and heavy metal contaminants situated at hazardous waste sites around the globe (Fierens et al. 2003; Järup 2003). Chlorinated organic solvents and heavy metals are two frequently encountered classes of pollutants often observed in contaminated subsurfaces (Lien et al. 2007). Two techniques that are commonly used for eradicating organic wastes from these sites; mining and ignition, have been established to be ineffective and expensive (Lehr et al. 2001). The presence of heavy metals may inhibit biodegradation by either inhibiting enzymes involved in both biodegradation and microbial metabolism, thus compounding the problem of chlorinated organic contamination (Kuo and Genthner 1996). The effects include extended acclimation periods, reduced biodegradation rates, and failure of target compound biodegradation (Kuo and Genthner 1996).

Metals are known to exist in several diverse chemical and physical states such as soil-adsorbed species, ionic solutes, soluble complexed species, separate-phase solids or colloidal solutions, thus making it difficult to be able to adequately define the effects of heavy metal toxicity on organic pollutant biodegradation in co-contaminated sites. The fact that the chemical and physical forms of heavy metals is influenced by environmental surroundings such as $\mathrm{pH}$ and ionic strength of the water phase as well as soil characteristics such as organic matter content, ion exchange capacity as well as clay type and content, further complicates remediation in these co-contaminated sites (Sandrin and Maier 2003).

An extensive list of reported metal concentrations that cause inhibition of biodegradation of organic contaminants has been presented by Sandrin and Maier (2003). There is also a wide range of reported inhibitory metal concentrations in the literature. For instance, five orders of magnitude separate lowest reported concentrations of zinc that inhibit biodegradation. Said and Lewis (1991) demonstrated that copper, mercury, chromium (II), cadmium and zinc are able to inhibit biodegradation of 2,4-DME in lake water samples inoculated with either a sediment or an aufwuch (floating algal mat) sample. In the sediment samples, zinc was most toxic, with an MIC of $0.006 \mathrm{mg}$ total zinc/L, however, in samples that contained aufwuchs, mercury was most toxic, with an MIC of $0.002 \mathrm{mg}$ total mercury/L. In a study, using a pure culture of naphthalene (NAPH)degrading Burkholderia sp., a MIC of $1 \mathrm{mg}$ solution-phase cadmium/L was reported (Sandrin et al. 2000). A comparable MIC was reported by Said and Lewis (1991) for cadmium $(0.1 \mathrm{mg}$ total cadmium/L for sediment samples and $0.629 \mathrm{mg}$ total cadmium/L for aufwuch samples). The variation between these MICs is thought to be organism/ community specific. Springael et al. (1993) demonstrated that metals will possibly inhibit biodegradation of pollutants by several bacteria genera under pure culture settings. However, the MICs reported in this study were 2-4 orders of magnitude greater than those formerly described by Said and Lewis (1991). This huge inconsistency is possibly owing to discrepancies in test conditions. Also, the board 
range of reported inhibitory concentrations can be attributed to divergences in experimental protocols that affect solution-phase metal concentrations. For example, many laboratory media contain metal-binding (e.g. yeast extract) and metal-precipitating (e.g. phosphate or sulfate salts) components that can reduce solution-phase metal concentrations (Hughes and Poole 1991). Medium pH can also considerably impact on solution-phase metal concentrations which become diminished as the $\mathrm{pH}$ is raised. This is due to metals forming insoluble metal oxides and phosphates (Crannell et al. 2000). Hughes and Poole (1991) stress the importance of understanding metal speciation in the test system. Unfortunately, few studies provide speciation information and as a result, an enormous range of metal concentrations has been reported to inhibit organic biodegradation.

The effects of $\mathrm{Hg}(\mathrm{II}), \mathrm{Cu}(\mathrm{II}), \mathrm{Cd}(\mathrm{II})$ or $\mathrm{Cr}(\mathrm{VI})$ at concentrations ranging from 0.01 to $100 \mathrm{ppm}$ on degradation of 2-chlorophenol (2CP), 3-chlorobenzoate (3CB), phenol, and benzoate by anaerobic bacterial consortia was investigated by Kuo and Genthner (1996). Three effects were observed, including extensive acclimation times (0.1-2.0 ppm), reduced dechlorination or biodegradation rates $(0.1-$ $2.0 \mathrm{ppm}$ ) and failure to dechlorinate or biodegrade the target compound (0.5-5.0 ppm). The biodegradation of 3CB was established to be the most susceptible to $\mathrm{Cd}(\mathrm{II})$ and $\mathrm{Cr}(\mathrm{VI})$. Biodegradation of benzoate and phenol was most susceptible to $\mathrm{Cu}$ (II) and $\mathrm{Hg}$ (II), in that order. Either specific or general variations in the bacterial populations could account for differences in metal sensitivity between the phenol and benzoate consortia. The biotransformation of 2- and 3-chlorophenol (CP) was examined by Kong (1998) in anaerobic fresh and accustomed sediments in the occurrence and deficiency of $\mathrm{CuCl}_{2}, \mathrm{CdCl}_{2}$ and $\mathrm{K}_{2} \mathrm{Cr}_{2} \mathrm{O}_{7}$ ranging from 10 to $200 \mathrm{mg} / \mathrm{L}$. Various inhibitory effects of certain metals were noticed on dechlorination of CPs in sediment slurries. In case of fresh unacclimated slurry, addition of $20 \mathrm{mg} \mathrm{Cu} / \mathrm{L}$ resulted in no substantial reduction of dechlorination for tested CPs. In contrast, $20 \mathrm{mg} / \mathrm{L}$ of $\mathrm{Cd}$ and $\mathrm{Cr}$ reasonably affected lag periods preceding dechlorination. In this case, $\mathrm{Cd}$ was more inhibitory than either $\mathrm{Cu}$ or $\mathrm{Cr}(\mathrm{Cd}>\mathrm{Cr} \geq \mathrm{Cu})$, which demonstrates almost comparable outcomes. In case of the accustomed slurry, the dechlorination activity of 2- and 3-CP was inhibited in the presence of $20 \mathrm{mg} / \mathrm{L}$ of three tested metals. Metals amended to 2- and 3-CP acclimated sediments exhibited inhibition degree in the order of $\mathrm{Cd}>\mathrm{Cu}>\mathrm{Cr}$, which are different patterns compared to fresh slurry. The effect of a transition metal, cadmium (Cd), on reductive dechlorination of a model chlorinated organic, 2,3,4-trichloroaniline (2,3,4-TCA), was determined in the laboratory by Pardue et al. (1996) in three anaerobic, flooded soil types with varying properties. Dechlorination of 2,3,4-TCA was inhibited over a range of pore-water-soluble $\mathrm{Cd}$ concentrations $(10-200 \mu \mathrm{g} / \mathrm{L})$ in mineral-dominated rice paddy and bottomland hardwood soils. In organic-dominated marsh soil, however, a critical inhibitory level of pore watersoluble Cd $(200 \mu \mathrm{g} / \mathrm{L})$ was observed. Lower-chlorinated aniline metabolites differed with soluble $\mathrm{Cd}$ concentration. Different metabolites (2,3-dichloroaniline and 2-chloroaniline) were observed in some soil types as $\mathrm{Cd}$ neared the completely inhibitory concentration. Speciation of soluble $\mathrm{Cd}$ was necessary to predict whether inhibition would occur, particularly in the presence of high concentrations of organic ligands such as humic acids.

Not all studies can correlate heavy metal effects and biodegradation inhibition. It has been demonstrated that heavy metals did not negatively impact on the biodegradation of organic compounds. For example, Baldrian et al. (2000) showed the degradation of polycyclic aromatic hydrocarbons by fungus Pleurotus ostreatus in the presence of cadmium and mercury. It is possible that the metals were being sequestered by a component of the solid medium used in these studies, therefore not being available to the organisms. Said and Lewis (1991) and Kuo and Genthner (1996) have also demonstrated that biodegradation could be stimulated in response to heavy metals. In this situation, a dose-dependent relationship occurs between metal concentration and biodegradation, however, when microbial consortiums are faced with selective pressure at higher metal concentrations, the dose-dependent relationship can no longer exist. Said and Lewis (1991), observed that an aerobic consortium of microbes degraded 2,4-dichlorophenoxyacetic acid methyl ester at a faster rate when exposed to $100 \mu \mathrm{M}$ cadmium than when exposed to $10 \mu \mathrm{M}$ cadmium. This increase may be due to only the most resistant microbes being able to survive when exposed to higher metal concentrations and hence these resistant microbes no longer needed to out-compete less resistant microbes for a carbon source. Another possible explanation is that when faced with higher metal concentrations, the metal resistance mechanisms now become more rapidly induced therefore increasing biodegradation (Worden 2008).

\section{Remediation strategies to improve biodegradation in co-contaminated sites}

Previous approaches to increasing organic biodegradation in the presence of metals involve reduction of metal bioavailability and the use of metal-resistant bacteria, treatment additives, and clay minerals. The addition of divalent cations and adjustment of $\mathrm{pH}$ are additional strategies under investigation. An extensive review on these strategies is documented in a review compiled by Sandrin and Maier (2003). In the current review, more attention is 
focused on biosorption, and other approaches using biosurfactants, zero-valent irons and cyclodextrin to enhance the bioremediation of sites co-contaminated with chlorinated hydrocarbons and heavy metals.

\section{Bioaugmentation}

There have been numerous reports on bioaugmentation of sites contaminated with only chlorinated organic compounds, however, only a small number cover inoculation with metal-resistant bacteria to stimulate organic contaminant biodegradation in a co-contaminated system (Sandrin and Maier 2003). Roane et al. (2001) used an approach which involved the inoculation of a cadmium-resistant Pseudomonas $\mathrm{H} 1$, and organic-degrading Alkaligenes eutrophus JMP134 into soil microcosms, with the aim to detoxify cadmium so that organic 2,4-dichlorophenoxyacetic acid (2,4-D) degradation was no longer inhibited. It was established that sequestration by heavy metal-degrading microorganisms reduced the bioavailable metal concentration and promoted even higher 2,4-D biodegradation rates. This technique was also demonstrated by Fernandes et al. (2009) where bacterial strains capable of withstanding considerable concentrations of $\mathrm{Cd}^{2+}$ or $\mathrm{Hg}^{2+}$ or $\mathrm{Pb}^{2+}$ were coupled with strains that showed good performance at degrading the pollutants methyl tertiary butyl ether or trichloroethane. Another strategy that has the potential to tackle the co-contamination predicament involves the utilization of a microorganism that can withstand and thrive in sites contaminated with heavy metals and still be able to exhibit unimpaired biodegradation. If microorganisms can display both of these properties it can be considered important for the remediation of those environments contaminated by organic xenobiotic compounds and heavy metals. Plasmid-borne heavy metal resistance and haloaromatic degrading functions were transferred into A. eutrophus strain by intra-specific conjugation (Springael et al. 1993), resulting in the strain being able to express both metal resistance and degrading functions. This was proven by observing degradation of different polychlorinated biphenyl isomers and 2,4-D in the presence of $2 \mathrm{mM}$ zinc or $1 \mathrm{mM}$ nickel, provided that the metal resistance determinant was present in the catabolizing strain (Springael et al. 1993). Another approach was the use of trichloroethane (TCA)-degrading rhizobacteria that can survive and thrive in soil polluted with heavy metals. Lee et al. (2006), engineered a TCA-degrading strain by introducing a gene encoding EC20 (metal-binding peptide) into the bacterium. This resulted in a strain with both heavy metal sequestration and TCA degradation potential. An ice-nucleation protein anchor allowed EC20 to be displayed onto the cell surface of Pseudomonas strain Pb2-1 and Rhizobium strain 10320D.
Cells that did not exhibit EC20 expression had a reduced rate of TCA degradation. However, cells expressing EC20 showed greater cadmium uptake and fully restored TCA degradation. It was established that EC20 expression can reduce the toxic effect of cadmium on TCA degradation by cadmium accumulation. Growing strains have been shown to be superior for degradation of a xenobiotic compound compared to resting cells. Accordingly, supplying nutrients or carbon sources together with the introduced bacterium can promote biodegradation. Introduction of bacteria that are sensitive to heavy metals but still retain activity against the organic contaminant in heavy metal-contaminated environments could lead to decreased degradation in time and may require subsequent inoculation of the organisms (Springael et al. 1993). To enhance the biodegradative potential of microorganisms, special attention has recently been focused on the transfer of packaged catabolic genes from one or more donor strains to indigenous microflora existing in contaminated areas (Mrozik and PiotrowskaSeget 2010).

\section{Use of zero-valent iron for remediation}

Zero-valent iron metal (ZVI) is one of the most plentiful metals on the globe (Deng et al. 2000). The use of ZVI as reactive medium for water management is one of the most potential methods because the iron metal is not expensive, easily accessible and has excellent competence and capacity of degrading contaminants (Hardy and Gillham 1996). As zero-valent iron is a strong reducer; it has been used to remove several contaminants as well as acting as a substitute to pump and treat and air-sparging technologies (Gibb et al. 2004). Reactive barriers enclosing iron metals are currently being developed for in situ treatment technology (Puls et al. 1999). In addition, iron waste particles from industrial filings can be used as a zero-valent iron (Lee et al. 2003).

Zero-valent iron has been used to rapidly dechlorinate an extensive array of chlorinated organic compounds (Table 1) following the mechanism described below. The favored electron acceptor is normally dissolved oxygen under aerobic conditions. Chlorinated hydrocarbons that have equivalent oxidizing potentials to oxygen can contend with dissolved oxygen as an electron acceptor. Aerobic groundwater enters the iron fillings wall, and causes the oxidation of metallic iron $\left(\mathrm{Fe}^{0}\right)$ to ferrous iron $\left(\mathrm{Fe}^{2+}\right)$ with the discharge of two electrons. Increasing the surface area of iron greatly increased the rate at which carbon solvents respond as electron acceptors, resulting in dechlorination and release of a chloride ion (Junyapoon 2005). The reaction takes place in a number of steps thus reducing halogenated organic compounds via intermediates, to non- 
Table 1 List of contaminants amenable to zero-valent iron treatment

\begin{tabular}{ll}
\hline Organic compounds & Inorganic compounds \\
\hline Methanes & Trace metals \\
Tetrachloromethane & Arsenic \\
Trichloromethane & Cadmium \\
Dichloromethane & Chromium \\
Ethanes & Cobalt \\
Hexachloroethane & Copper \\
1,1,1-trichloroethane & Lead \\
1,1,2-trichloroethane & Manganese \\
1,1-dichloroethane & Nickel \\
1,2-dibromoethane & Selenium \\
Ethenes & Uranium \\
Tetrachloroethene & Zinc \\
Trichloroethene & \\
cis-1,2-dichloroethene & \\
trans-1,2-dichloroethene & Anion contaminants \\
1,1-dichloroethene & Nitrate \\
Vinyl chloride & Phosphate \\
Propanes & Sulfate \\
1,2,3-trichloropropane & \\
1,2-dichloropropane & \\
Others & \\
Benzene & \\
Toluene & \\
Ethylbenzene & \\
Fexachlorobutadiene & \\
$n$-nitrosodimethylamine & \\
\hline Ad & \\
\hline
\end{tabular}

Adapted from Junyapoon (2005)

hazardous compounds. Intermediate compounds like vinyl chloride, which has a higher toxicity than the parent, are not produced in elevated concentrations. The ultimate products of the reaction are simple hydrocarbons like ethylene, ethane and acetylene. High temperature is not a requirement for the reaction to continue, therefore making it thermodynamically feasible. The lower the degree of chlorination, the slower the rate of the dechlorination reaction (Janda et al. 2004). A few of the many reported occurrences of zero-valent iron involved in dechlorination is described below. Gotpagar et al. (2007) investigated the reductive dehalogenation of trichloroethylene (TCE) using zerovalent metals. The degradation rate was found to be first order with respect to the organic molecule, thus the conversion was independent of initial TCE concentration. The quantity of TCE degraded at any given time was established to be directly proportional to the dissolved iron in solution. The metal surface area plays an important role in the process. Twofold increase in the pseudo-first-order rate constant was obtained when the metal particle size was decreased from $370 \mu \mathrm{m}$ by a factor of 2.5 . Reduction of chlorinated solvents by fine-grained iron metal was studied by Matheson and Tratnyek (1994), in well-mixed anaerobic batch systems in order to help assess the utility of this reaction in remediation of contaminated groundwater. Iron sequentially dehalogenates carbon tetrachloride via chloroform to methylene chloride. The initial rate of each reaction step was pseudo-first-order and became considerably slower with each dehalogenation step. Thus, carbon tetrachloride degradation typically occurred in several hours, but no noteworthy reduction of methylene chloride was observed over 1 month. Trichloroethane was also dechlorinated by iron, although more gradually than carbon tetrachloride. Increasing the surface area of iron greatly increased the rate of carbon tetrachloride dehalogenation, whereas increasing $\mathrm{pH}$ decreased the reduction rate slightly. Figure 1 provides an overview of the mechanisms involved in the degradation of volatile organic carbons by ZVI (Matheson and Tratnyek 1994). Lookman et al. (2004) found that 1,1,1-trichloroethane (1,1,1-TCA) was quickly degraded by three types of granular zero-valent iron in a series of laboratory batch experiments using polluted groundwater, with and without added aquifer material. Two types of iron were able to reduce 1,1,1-TCA completely with no increase in the concentration of the daughter products (1,1-dichloroethane; chloroethane), while one type of iron showed slower 1,1,1-TCA reduction, with intermediate rise of daughter products. A review by Gunawardana et al. (2011) evaluated the impacts of ZVI and bimetals on the rate and degree of chlorophenol dechlorination. A study by Truex et al. (2011) suggests that ZVI can induce dechlorination in an aquifer by directly injecting it into the aquifer with shear-thinning fluids and this extends the applicability of ZVI to situations where other emplacement methods may not be viable.

Zero-valent iron is also considered as a probable remediation agent for the abolition of many heavy metals from contaminated groundwater. Various heavy metal interactions such as reduction, co-precipitation and surface complexation have lead to ZVI technology becoming an effective means for the removal of heavy metals with different chemical properties (Shokes and Moller 1999). Recent studies suggest that ZVI has metal removal capacity much higher than conventional sorbents such as activated carbon, zeolites and polymeric ion exchange resins ( $\mathrm{Li}$ and Zhang 2007). Mechanisms for metal removal by ZVI are seemingly complex and not well understood ( $\mathrm{Li}$ and Zhang 2007). However, the degradation mechanisms are founded on transformation from hazardous to non-hazardous forms or adsorption on the iron surface depending on the type of heavy metals (Junyapoon 2005). Chromate undergoes a reductive reaction in ZVI systems where chromium serves as the oxidizing agent. The removal of chromium by zero- 
valent iron is based on transformation from toxic to nontoxic forms. Trivalent chromium [Cr(III)], which is less toxic and less water soluble and connected with solids can be the product of transformation with ZVI from hexavalent chromium, which is a strong oxidant, a potential carcinogen and more mobile in aquifers (Junyapoon 2005). The elimination of the reduced chromium species $\mathrm{Cr}$ (III) occurs through precipitation of the sparingly soluble $\mathrm{Cr}(\mathrm{OH})_{3}$ or precipitation of mixed iron(III)-chromium(III) (oxy) hydroxide solids (Dries et al. 2005). Removal of metals can occur without reduction to metallic form, for example, arsenic can be removed used using ZVI, a method involving surface complexation. Iron hydroxide (active phase) has to be formed on the surface of the particles before arsenic can be bound to this material under oxidizing conditions $(\mathrm{Ju}-$ nyapoon 2005). Zinc $\left[\left(E^{\circ}\right)-0.76 \mathrm{~V}\right]$, which is more electronegative than ZVI, does not react with ZVI to form reactive zero-valent $\mathrm{Zn}^{0}$, but takes part in surface complexation reactions with the iron oxides present on the ZVI surface. The basis for these sorption reactions is the corrosion of ZVI, forming amorphous ferrous hydroxide and mixed valent iron salts, known as green rust (Dries et al. 2005). In a study by Alshaebi et al. (2009), it was found that ZVI that has proportion of $95 \%$ iron, and $2.5 \%$ of lime and carbon showed very high adsorption on arsenic (As) with the percentage of removal ranging from 97.02 to $99.95 \%$. The results showed that the increasing proportion of carbon and limestone will reduce the ability of the sample to adsorb As. Boparai et al. (2011) investigated the use of nano zerovalent iron (nZVI) particles for the removal of $\mathrm{Cd}^{2+}$ and concluded that nZVI can be used as an effective adsorbent for removing cadmium from contaminated water sources, with a maximum adsorption capacity of $769.2 \mathrm{mg} \mathrm{g}^{-1}$ $\mathrm{Cd}^{2+}$ observed. Increasing the temperature improved the cadmium adsorption rate; however, the maximum adsorption capacity was similar. A review by Gheju (2011) provides updated information regarding the developments and innovative approaches in the use of ZVI for the treatment of $\mathrm{Cr}(\mathrm{VI})$-polluted waters. Improved methods that involve physical and chemical processes include (1) increasing the surface area of iron by reducing its particle size to augment the reactivity; (2) merging ultrasound and iron to accelerate dechlorination reaction and reduce the formation of oxide layers on the surface of the iron by incessant cleaning through acoustic cavitation; and (3) depositing a second metal as a catalyst onto the surface of the iron (Lin et al. 2004). Rates of dechlorination by iron have been increased by using palladium, a known hydro-dechlorination catalyst (Grittini et al. 1995; Cheng et al. 1997), as a coating on the zero-valent iron surface. Four amended irons prepared by coating iron with palladium $(\mathrm{Pd} / \mathrm{Fe})$, platinum $(\mathrm{Pt} / \mathrm{Fe})$, nickel $(\mathrm{Ni} / \mathrm{Fe})$, and copper $(\mathrm{Cu} / \mathrm{Fe})$ were also used and showed slower removal rates as compared to unamended iron, estimated half-lives of 36-43 days (Kim and Carraway 2000). Iron granules $(<10 \mu)\left(\mathrm{Fe}^{0}-\mathrm{H}_{2} \mathrm{O}\right)$ and palladium-treated iron granules $\left(\mathrm{Pd} / \mathrm{Fe}^{0}-\mathrm{H}_{2} \mathrm{O}\right)$ in contact with water have been tested as a potential means to dechlorinate chloromethanes $\left(\mathrm{CCl}_{4}, \mathrm{CHCl}_{3}\right.$, and $\left.\mathrm{CH}_{2} \mathrm{Cl}_{2}\right)$ that are commonly generated in teaching chemistry laboratories. Palladium treatment enhanced the rate of dechlorination of $\mathrm{CCl}_{4}$ by a factor of about seven compared to the untreated $\mathrm{Fe}^{\mathrm{O}}$ $\mathrm{H}_{2} \mathrm{O}$, but the potential toxic effect of palladium remains a concern (Wan et al. 1998). Oxygen in the aqueous solution reduced the dechlorination rates of $\mathrm{CCl}_{4}$ with both $\mathrm{Fe}^{0}-\mathrm{H}_{2} \mathrm{O}$ and $\mathrm{Pd} / \mathrm{Fe}^{0}-\mathrm{H}_{2} \mathrm{O}$ by at least a factor of three. Nevertheless, from the consideration of remediating solvent wastes, both systems appear suitable for treating $\mathrm{CCl}_{4}$ and possibly $\mathrm{CHCl}_{3}$ wastes, even in the presence of oxygen (Wan et al. 1998). Chlorinated organic compounds detoxification via reaction with nickel/iron powder was carried out in aqueous solution where nickel/iron bimetallic powder was observed to have higher hydro-dechlorination activities for both atrazine and $p$-chlorophenol, compared to iron (Shao-ping et al. 2005). Numerous studies have indicated that ZVI are effective for removing chlorinated hydrocarbons and heavy metals separately, however, limited studies have been performed to evaluate the effectiveness of ZVI to remediate sites co-contaminated with both these pollutants. In some instances, the presence of heavy metals can be used as an advantage because it can be utilized as a source of a second metal which leads to the in situ formation of bimetallic iron nanoparticles when monometallic iron nanoparticle were implemented (Lien et al. 2007). Wang et al. (2011a) found that in the presence of certain metals, dechlorination increased. Divalent metal ions, $\mathrm{Co}^{2+}, \mathrm{Cu}^{2+}$, and $\mathrm{Ni}^{2+}$, were reduced and formed bimetals with $\mathrm{nZVI}$, thereby enhancing the dechlorination of 4-chlorobiphenyl.

Treatments of mixed contaminants containing both chlorinated organic compounds and toxic metals using reactive iron have received attention in the last decade. Dries et al. (2005) investigated the combined removal of the chlorinated ethenes; perchloroethylene (PCE) and TCE and the heavy metals $\mathrm{Cr}(\mathrm{VI}), \mathrm{Zn}(\mathrm{II})$ and $\mathrm{Ni}(\mathrm{II})$ from simulated groundwater by ZVI. PCE and TCE were almost completely removed in continuous column systems both with and without a mixture of the heavy metals present. In both systems, the main chlorinated ethene degradation product found was cis-1,2-DCE, although it appeared in considerably lower concentrations in the effluent of the heavy metal-loaded columns. Heavy metal removal ranged from 97 to $100 \%$. In a supporting batch test, the presence of $\mathrm{Ni}$ (II) was found to enhance the TCE reduction kinetics by iron, while $\mathrm{Cr}(\mathrm{VI})$ significantly inhibited the reaction. The higher efficiency of the metal-containing columns could thus be explained by an enhanced nickel-catalysed dechlorination activity resulting from $\mathrm{Ni}$ plating on the iron 
A Direct Reduction at the Metal Surface

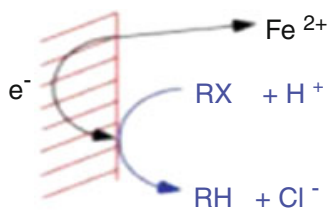

\section{B Reduction by Ferrous Iron}

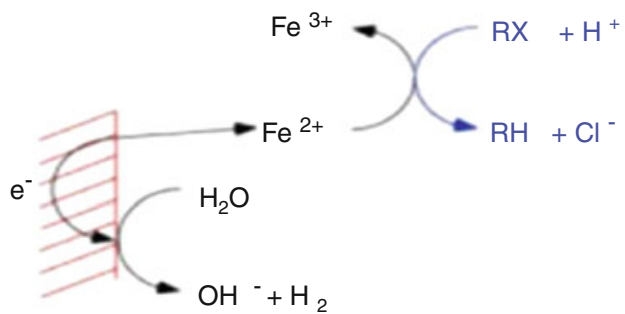

C Reduction by Hydrogen with Catalysis

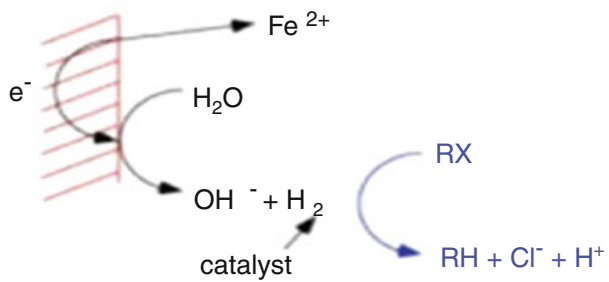

Fig. 1 The various reduction mechanisms implicated in the degradation of volatile organic carbons by zero-valent iron (Matheson and Tratnyek 1994)

filings. The dechlorination of carbon tetrachloride $\left(\mathrm{CCl}_{4}\right)$ by iron nanoparticles was found to be enhanced by $\mathrm{Cu}(\mathrm{II})$ but led to more benign products (i.e. $\mathrm{CH}_{4}$ ) being produced. It was also found that reaction rates were increased slightly by $\mathrm{Pb}$ (II) but also increased the production of more toxic intermediates such as dichloromethane. In comparison to the iron reduction system without heavy metals, effects of $\mathrm{As}(\mathrm{V})$ were negligible while $\mathrm{Cr}(\mathrm{VI})$ decreased the dechlorination rate by a factor of 2 (Lien et al. 2007). The possibility of using zero-valent silicon $\left(\mathrm{Si}^{0}\right)$ as a novel reductant to remove chlorinated compounds and heavy metals in contaminated sites was investigated by Doong et al. (2004). They showed that zero-valent silicon could effectively dechlorinate the chlorinated compounds. A nearly complete dechlorination of $\mathrm{CCl}_{4}$ by $\mathrm{Si}^{0}$ was obtained within $14 \mathrm{~h}$ with reductive dechlorination found to be the major degradation pathway. In addition, zerovalent silicon has a high capability in the removal of heavy metals with $83 \%$ of $\mathrm{Cr}(\mathrm{VI})$ removed by $0.5 \mathrm{~g} \mathrm{Si}^{0}$ within $5 \mathrm{~h}$, which is higher than that by $\mathrm{Fe}^{0}$. The removal efficiency of divalent metal ions by $\mathrm{Si}^{0}$ followed the order: $\mathrm{Cu}$ (II) $>\mathrm{Pb}$ (II) $>\mathrm{Ni}$ (II), thus indicating that zero-valent silicon is an alternative reductant and can undergo coupled reduction of heavy metals and chlorinated hydrocarbons in contaminated groundwater.

\section{Cyclodextrin as a remediation option}

Cyclodextrin (CD), a cyclic oligosaccharide formed from the enzymatic degradation of starch by bacteria, has the potential to remediate contaminated water (Brusseau et al. 1997). Cyclodextrins solubilize low-polarity organic compounds by inclusion complexation, wherein the solutes "partition" into the cyclodextrin cavity (Del Valle 2004). Figure 2 illustrates the structure of cyclodextrin (Davis and Brewster 2004). The formation of CD-contaminant complexes significantly increases the apparent solubility of many low-soluble organic contaminants as well as enhance their desorption and transport, which is the basis for the use of CD in groundwater remediation (US Department of Defense 2004). CD, being a sugar, is known to be relatively non-toxic to humans, plants, and soil microbes. Therefore, there are minimal health-related concerns linked to the addition of cyclodextrin into the subsurface, which is an intrinsic benefit for its use as a remediation option (Tick et al. 2003). Chemical properties of interest such as aqueous solubility and metal complexation potential can be altered by substituting functional groups to the outside of the cyclodextrin. Laboratory and field studies have demonstrated that hydroxypropyl- $\beta$-cyclodextrin (HPCD) has high aqueous solubility and strongly enhances solubility of organic compounds (Boving and McCray 2000). Specific CDs, such as modified $\mathrm{CD}$, carboxymethyl- $\alpha$-cyclodextrin (CMCD), can bind cationic metals by complexation interactions between metal ions and the acidic functional groups (e.g. carboxyl) associated with the external surfaces of the cyclodextrin. Carboxymethyl- $\beta$-cyclodextrin enhances the solubility of common metal contaminants making it a potential agent for in situ remediation of metals. The solubility enhancement is greater for heavy metals than for group 2 elements; however, the presence of soluble minerals composed of non-target elements would affect the extent of the solubility of the target metal (Skold et al. 2009). It was established that the optimum concentration for the complexation of lead ions with CMCDs was below $5 \mathrm{~g} / \mathrm{L}$. Any higher concentration will result in inefficient complexation, because higher concentrations of CMCD alter the ionic strength of the solution which in turn alters the explanation of the non-ideal behavior of CMCD. The mechanism of this effect is not well known (Skold et al. 2007). Chatain et al. (2004) found that CD could be used as an innovative means to facilitate the removal of both organic and inorganic contaminants by dissolving them, thus facilitating easy removal from the porous media. While cationic metals can be chelated by the oxygen atoms on the rime of the CMCD, hydrophobic organic pollutants can also be included within the nonpolar cavity of CD. Wang and Brusseau (1995) have shown that the solubilization of aromatic hydrocarbons (PAH) was not 
significantly affected at high concentrations of salts or metals in the aqueous phase because of the insignificant interaction of metals with the low-polarity cavity of CD. Using advanced analytical tools, one may be able to determine thermodynamic stability data involving chelating agents such as CMCD that are required for reliable estimates of metal transport and extraction (Chatain et al. 2004). If the complexing agent, or mixture of complexing agents, is chosen appropriately both organic and inorganic contaminants can be removed simultaneously (Mulligan et al. 2001). One potential complexing agent identified for cleaning up mixed waste is cyclodextrin (Skold et al. 2009). Cathum et al. (2006) investigated the effectiveness of a CD-based solid material for the removal of mixed dissolved contaminants in water. The removal efficiency was found to be $70 \%$ for total heavy metals (cadmium, lead, chromium, iron, nickel, cobalt, and mercury) to $98 \%$ for polychlorinated biphenyls (PCBs). The optimum $\mathrm{pH}$ for heavy metal removal was approximately 5 and for PCBs it was in the range of 5-7. The results also showed that the presence of alkaline and alkaline earth metals did not have a significant effect on the removal efficiency, indicating that the CD-based material could selectively remove the heavy metals of concern without being consumed by alkaline and alkaline earth metals.

Limited studies on the remediation of co-contamination using cyclodextrin in water have been carried out; however, studies were carried out in soil. Ehsan et al. (2007) evaluated the efficacy of a washing process with cyclodextrin in combination with ethylenediaminetetraacetate (EDTA) for the simultaneous mobilization of heavy metals and polychlorinated biphenyls from a field contaminated soil. Ultrasonically aided mixing of the field contaminated soil with a combination of cyclodextrin solution $(10 \%$; $\mathrm{w} / \mathrm{v})$ and a sparing quantity $(2 \mathrm{mM})$ of EDTA, simultaneously mobilized appreciable quantities of PCBs and much of the analyte metal $(\mathrm{Cd}, \mathrm{Cr}, \mathrm{Cu}, \mathrm{Mn}, \mathrm{Ni}, \mathrm{Pb}, \mathrm{Zn})$. Chatain et al. (2004) found the use of CMCD as a flushing agent to enhance the removal of both inorganic and organic pollutants from mixed-contaminated soils. For mixedwaste systems, the presence of the co-contaminant does not appear to significantly influence the complexation/solubilization of the other contaminant (Wang and Brusseau 1995). Wanga et al. (2010) used glycine- $\beta$-cyclodextrin (GCD) to enhance the remediation of soil co-contaminated with lead and the organic contaminant phenanthrene. At concentration of $40 \mathrm{~g} / \mathrm{L}, \mathrm{GCD}$ has a removal efficiency of 85.8 and $78.8 \%$ for lead and phenanthrene, respectively, from the combined contaminated soil. The study by Yang et al. (2010) demonstrated that glutamic acid- $\beta$-cyclodextrin could be successfully applied to remediation of heavy metals or organic compounds in contaminated soil.

\section{Biosorption}

Since 1990 s, the adsorption of heavy metal ions by lowcost renewable organic materials has gained momentum. Various types of adsorbents such as the activated carbon, zeolites and resins are employed. In view of the high cost of these adsorbents, more researches are geared toward biosorption (Azouaou et al. 2008). Biosorption, the passive uptake of pollutants such as heavy metals by biological materials, is emerging as a potential alternative to the existing conventional technologies for the removal and/or recovery of metal ions from aqueous solutions (Schiewer and Patil 2008). The utilization of seaweeds, moulds, yeasts, and other dead microbial biomass and agricultural waste materials for removal of heavy metals has been explored by many researchers and it was found that the major advantages of biosorption over conventional treatment methods include: low cost, high efficiency,
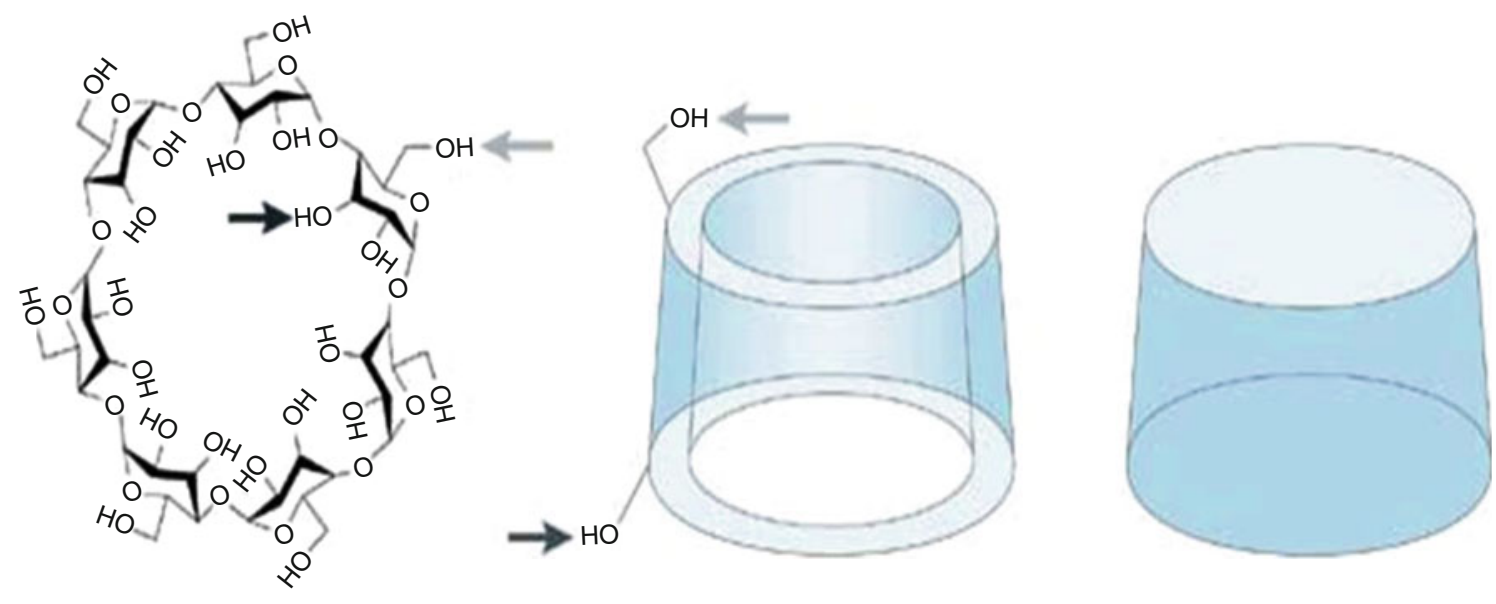

Fig. 2 Chemical structure of cyclodextrin (Davis and Brewster 2004) 
minimization of chemical or biological sludge, regeneration of biosorbents and possibility of metal recovery (Sud et al. 2008). However, the efficiency of biosorption is affected by several factors as described below:

\section{Temperature}

Temperature plays a key role in the adsorption of heavy metals and is one of the most significant criteria for the efficient removal of heavy metals from wastewater. Temperature changes influences a number of forceful factors which are significant in heavy metal ion biosorption, including: (1) the stability of the metal ion species initially placed in solution; (2) the stability of microorganism-metal complex depending on the biosorption sites; (3) microbial cell wall configuration; and (4) the ionization of chemical moieties on the cell wall. Temperature has two major effects on the adsorption process. One is that increasing the temperature will increase the rate of adsorbate diffusion across the external boundary layer and in the internal pores of the adsorbate particles because liquid viscosity decreases as temperature increases. The other one is that it affects the equilibrium capacity of the adsorbate depending on whether the process is exothermic or endothermic (Addagalla et al. 2009). The effect of temperature on the sorption of cadmium and chromium by olive stone was found to be insignificant; however, an increase in the sorption capacity for lead from 0.596 to $0.728 \mathrm{mg} / \mathrm{g}$ was obtained when the temperature was raised from 25 to $40{ }^{\circ} \mathrm{C}$. The optimum biosorption temperature for $\mathrm{Pb}(\mathrm{II}), \mathrm{Cu}(\mathrm{II})$ and $\mathrm{Ni}(\mathrm{II})$ by $R$. arrhizus was determined to be $25^{\circ} \mathrm{C}$; and that for $\mathrm{Cu}(\mathrm{II}), \mathrm{Cd}$ (II) and $\mathrm{Pb}$ (II) by S. cerevisiae was determined to be $25^{\circ} \mathrm{C}$ (Volesky and May-Phillips 1995). However, the optimum biosorption temperature of the same metal ions by Phanerochaete chrysosporium and by Streptomyces noursei were found to be $30^{\circ} \mathrm{C}$ (Say et al. 2001). On the other hand, Fe(III) and $\mathrm{Pb}$ (II) biosorption by Zoogloea ramigera was increased with increasing temperature up to $45{ }^{\circ} \mathrm{C}$ (Sag and Kutsal 2000). It was also reported that at low temperature the binding of heavy metal ions to the microorganisms occurred by a physical adsorption process and because of the low energy utilization, a balance between the cell wall surface and the metal ions was usually quickly and easily reversible (Sag and Kutsal 2000). Igwe and Abia (2007) studied the design parameters in the bioremediation of arsenic from aqueous solution using modified and unmodified coconut fiber. The result showed that a temperature of $30{ }^{\circ} \mathrm{C}$ and particle size of $0.6 \mathrm{~mm}$ was most suitable. The thermodynamic parameters evaluated including the sticking probability model indicate that the sorption process was exothermic, physiosorption and diffusion controlled.
$\mathrm{pH}$

The effect of $\mathrm{pH}$ can be explained by the availability of negatively charged groups at the biosorbent surface which is necessary for sorption of metals to proceed. This is unlikely at the highly acidic $\mathrm{pH}$ of two when a net positive charge is produced in the system due to $\mathrm{H}^{+}$and $\mathrm{H}_{3} \mathrm{O}^{+}$. In such a system, $\mathrm{H}^{+}$competes with metal ions, resulting in protonation of active sites to the virtual exclusion of metal binding on the biosorbent surface. This means that at higher $\mathrm{H}^{+}$concentration, the adsorbent surface is further positively charged thus dropping the attraction between adsorbent and metal cations. In contrast, as the $\mathrm{pH}$ increases, more negatively charged surface becomes accessible, consequently allowing for greater metal uptake (Abdel-Ghani et al. 2007). Abdel-Ghani et al. (2007) found the optimum $\mathrm{pH}$ for metal removal to range from 4.5 to 6.5. At these mentioned $\mathrm{pH}$ optima, lead removal, using the biosorbents; rice husks, maize cobs and sawdust, reached $99 \%$. The role of $\mathrm{pH}$ in $\mathrm{As}(\mathrm{V}), \mathrm{Pb}(\mathrm{II})$ and $\mathrm{Hg}(\mathrm{II})$ ions detoxification by bio-sorption from aqueous solutions using coconut fiber and sawdust waste biomass, containing chelating agents was studied by Igwe et al. (2005). It was shown that adsorption could be influenced by $\mathrm{pH}$ with maximum adsorption found to occur at $\mathrm{pH} 2$ and 12, whereas minimum adsorption occurred at $\mathrm{pH}$ 6-8. In a study by Vasudevan et al. (2003), the cadmium(II) ion adsorption capacity of sorbent was found to increase with increasing $\mathrm{pH}$, and was maximum at a $\mathrm{pH}$ of 6.5. Also, $\mathrm{pH}$ was found to influence the sorption capacity of activated sludge for heavy metals, with a $\mathrm{pH}$ of 4 reported to be the optimum for the adsorption capacity of the sludge (Addagalla et al. 2009). The effect of $\mathrm{pH}$ on the sorption capacity of prepared carbon was studied by Khan and Wahab (2007) and the most efficient sorption was found to occur at a $\mathrm{pH}$ of 4.5. At this value, the dominant species of copper mainly involved in the sorption process was free $\mathrm{Cu}^{2+}$ ion. Further experiments at higher values were hindered owing to the immediate precipitation of blue copper hydroxide. The effect of $\mathrm{pH}$ on the removal efficiency of total chromium onto $C$. virgatum was studied at a $\mathrm{pH}$ range of 1-8. The highest removal of total chromium was found at $\mathrm{pH} 1.5$, with a decreased removal observed with an increase in $\mathrm{pH}$ (Sar and Tuzen 2008). Ning-chuan et al. (2010) demonstrated that at low $\mathrm{pH}$ values the adsorption of $\mathrm{Cu}$ (II) onto modified orange peels is low, however, an increase in $\mathrm{pH}$ from 2.5 to 4.5 lead to an increase in copper adsorption, with the highest adsorption efficiency observed between pH 4.5 and 6.0. Murthy et al. (2011) found that the adsorption of $\mathrm{Cu}$ (II) onto coconut shell powder in aqueous solution was found to increase from $42 \%$ at pH 5 to $96 \%$ at $\mathrm{pH}$ 9. Gonen and Serin (2012) observed that at a pH 3, adsorption of $\mathrm{Ni}$ (II) ions onto orange peel was at a 
minimum, however, as the $\mathrm{pH}$ is increased adsorption increases, with maximum adsorption observed at $\mathrm{pH} 5$.

Agricultural waste as a biosorbent material

Recently, attention has been diverted toward byproduct material or wastes from large scale industrial operations and agricultural materials. Cellulosic agricultural waste materials are an abundant source for significant metal biosorption. The functional groups present in agricultural waste biomass viz., acetamido, alcoholic, carbonyl, phenolic, amido, amino and sulphydryl groups have affinity for heavy metal ions to form metal complexes or chelates (Sud et al. 2008). The functional groups can be determined by Fourier transform infrared spectrometry (Li et al. 2008). Some biosorbents are non-selective and bind to a wide range of heavy metals with no specific priority, whereas others are specific for certain types of metals depending on their chemical composition (Wang and Brusseau 1995). The mechanism of biosorption process includes hemisorptions, complexation, adsorption on surface, diffusion through pores and ion exchange (Sud et al. 2008). The use of fruit wastes for the removal of heavy metal ions from wastewater has been reported. Orange peel was found to be an efficient biosorbent capable of removing heavy metal ions from wastewater (Schiewer and Patil 2008). Also, another cellulosic material, maize cob, was used to establish the mode of adsorption of the metal ions on the adsorbent by calculating the intraparticulate diffusivity and the fractional attainment of equilibrium (Igwe and Abia 2005). It was found that the mode of adsorption could be particle diffusion or film diffusion controlled depending on the metal ion type and the adsorbent type. It was also shown that coconut fiber was capable of removing heavy metals from waste water (Igwe and Abia 2007). A study on the ability of some vegetable wastes, released in nature, to remove cadmium from aqueous solution by adsorption was undertaken, using some selected adsorbents; orange barks, olive cores and olive wastes. The results obtained showed that the orange barks are more competitive with a maximum adsorption capacity of $31.01 \mathrm{mg} / \mathrm{g}$ compared to the olive cores $(12.56 \mathrm{mg} / \mathrm{g})$ and the olive wastes $(6.55 \mathrm{mg} / \mathrm{g})$ (Azouaou et al. 2008).

Various agricultural biosorbents were assessed by Surchi (2011) for their $\mathrm{Pb}$ ion removal efficacy. Chalf, rice husk, sesame husk, sunflower husk and tea waste were found to remove $85,90,100,86,98 \% \mathrm{~Pb}$ ions, respectively. Abdel-Ghani et al. (2007) investigated the adsorption efficiency of rice husk, maize cobs and sawdust for the removal of $\mathrm{Pb}$ (II) from aqueous systems. Rice husk was the most effective, with $98.15 \%$ of $\mathrm{Pb}$ removed at room temperature. The removal of $\mathrm{Zn}, \mathrm{Cd}$ and $\mathrm{Pb}$ using maize cob was studied by Akporhonor and Egwaikhide (2007) with the highest sorption rates of $71 \%$ for $\mathrm{Zn}^{2+}, 32 \%$ for $\mathrm{Cd}^{2+}$, and $30 \%$ for $\mathrm{Pb}^{2+}$ observed. The capacity and efficiency of maize cob carbon in removing $\mathrm{Zn}^{2+}, \mathrm{Ni}^{2+}$ and $\mathrm{Cd}^{2+}$ ions from aqueous solutions and the effectiveness of the modified maize cobs in removing the metal ions from solution was found to be $\mathrm{Zn}>\mathrm{Ni}>\mathrm{Cd}$. A study of the biosorption of cadmium by pectin-rich fruit materials by Schiewer and Patil (2008) revealed that citrus peels were the most suitable biosorbent. This was attributed to higher stability coupled with good uptake than apple residues and grape skins. Kinetic studies showed that equilibrium was reached within 30-90 min, depending on particle size. The metal uptake rate increased as particle size decreased, indicating mass transfer limitations. There was little impact of particle size on capacity, indicating that biosorption by fruit wastes is not only a surface phenomenon. Schiewer and Balaria (2009) investigated the uptake of $\mathrm{Pb}^{2+}$ by processed orange peels, a pectin-rich byproduct of the fruit juice industry. Low $\mathrm{pH}$ increased ionic strength, or competing co-ions reduced $\mathrm{Pb}^{2+}$ binding at low sorbent dosages, but at high sorbent dosages removal remained above $90 \%$. Citrus peel biosorbents show high uptake, good kinetics and high stability, properties which hold high promise for industrial applications. The ability of banana peel biomass to remove various heavy metals from solution was evaluated by Ashraf et al. (2011). At a zinc concentration of $150 \mathrm{mg} / \mathrm{L}$, the removal of metal ions were $92.52 \%$ for lead, $79.55 \%$ for copper, $63.23 \%$ for zinc and $68.10 \%$ for nickel. Murthy et al. (2011) found that coconut shell powder had a high adsorption capacity for $\mathrm{Cu}$ (II), with more than $90 \%$ being adsorbed in batch experiments.

Apart from the use of agricultural biomass for heavy metal removal, studies have shown its potential application to organic pollutants. Imagawa et al. (2000) investigated the feasibility of using carbonized rice husk agricultural by-product, for the removal of chlorinated hydrocarbons from air and water by adsorption. It was shown that tetrachloroethylene, trichloroethylene and 1,1,1,-trichloroethane could be adsorbed by the carbonized rice husk. It has also been previously shown that rice husk can be used as an adsorbent for heavy metals (Kumar and Bandyopadhyay 2006). Adsorption of chlorophenols onto coconut coir pith carbon from aqueous solution was successfully demonstrated by Namasivayam and Kavitha (2006). In addition a review on coconut-based biosorbents highlights the use of coir pith for the removal of heavy metals (Bhatnagar et al. 2010). The ability of agricultural biosorbents to adsorb both heavy metals and chlorinated compounds renders it practicable for application in the remediation of co-contaminated sites. 
Desorption of heavy metal from biosorbent

The ability to recover heavy metals from biosorbents without destroying their sorption capability is also crucial (Lesmana et al. 2009). As noted in most studies, heavy metals can be recovered quite easily using various chemicals, although in several cases, the metal-binding capability deteriorates after regeneration. Attempts were made by Igwe et al. (2005) to regenerate the adsorbent as well as resolubilize the metal ions from the spent adsorption. Some amount of metal ions were adsorbed at a neutral $\mathrm{pH}$, with an increase in desorption from 20 to $50 \%$ when the concentration of $\mathrm{NaOH}$ was increased from $10^{-3}$ to $10^{-2} \mathrm{M}$. Lasheen et al. (2012) observed that regeneration and desorption of heavy metals from orange peel was achieved concurrently by acid elution and that the adsorption capability of the orange peel was retained completely even after four cycles of adsorption-elution.

\section{Biosurfactants}

Biosurfactants, such as rhamnolipids, are of particular interest for use in remediation technologies for several reasons: (1) they are naturally occurring products, more environmentally compatible and more economical than using modified clay complexes or metal chelators, such as EDTA and can thus be considered as "biodegradable" additives, (2) they are produced in great structural variety by many different microorganisms and may have unique metal-binding capacities and selectivities in comparison to available synthetic chelates or surfactants, and (3) there is potential for in situ production of biosurfactants (Herman et al. 1995). There are four types of rhamnolipids; type 1 (R1), a L-rhamnosyl- $\beta$-hydroxydecanoyl- $\beta$-hydroxydecanoate of molecular mass $504 \mathrm{Da}$, type II (R2), a L-rhamnosyl- $\beta$-L-rhamnosyl- $\beta$-hydroxydecanoyl- $\beta$-hydroxydecanoate of molecular mass $650 \mathrm{Da}$. The other two types of rhamnolipids contain either two rhamnoses attached to $\beta$-hydroxydecanoic acid or one rhamnose connected to the identical fatty acid. Rhamnolipid type I and type II, because of their molecular structure, they are suitable for soil washing and heavy metal removal (Mulligan and Wang 2006). Rhamnolipid like other surfactants is an amphiphilic compound with both hydrophobic and hydrophilic portions. (Dahrazma and Mulligan 2007).

The effect of biosurfactant on biodegradability of 2,4dichlorophenol (2,4-DCP) by activated sludge bioreactor was investigated by Uysal and Turkman (2005) using JBR 425 rhamnolipid as a biosurfactant. 2,4-DCP removal efficiency for control and test reactor ranged between 97.4-97.7 and 99.7-99.8\%, respectively, when the influent concentration of 2,4-DCP ranged between 30 and $100 \mathrm{mg} / \mathrm{L}$. The removal efficiency of 2,4-DCP decreased up to 24.2 and $32.9 \%$ in the control and test reactor, respectively, when the concentration of 2,4-DCP was increased from 100 to $150 \mathrm{mg} / \mathrm{L}$. In the test reactor, the presence of biosurfactant stimulated bacterial growth reduced the toxicity of 2,4-DCP to the microorganisms. A rhamnolipid, a glycolipid biosurfactant JBR215, was evaluated for the removal of heavy metals (copper, zinc, and nickel) from sediments by Dahrazma and Mulligan (2007). The removal of heavy metals from sediments was up to $37 \%$ of $\mathrm{Cu}$, $13 \%$ of $\mathrm{Zn}$, and $27 \%$ of $\mathrm{Ni}$ when rhamnolipid without additives was applied. Adding $1 \% \mathrm{NaOH}$ to $0.5 \%$ rhamnolipid improved the removal of copper by up to four times compared with $0.5 \%$ rhamnolipid alone. Lead removal from water and contaminated soils was investigated using biosurfactant, anionic, and nonionic surfactants in continuously stirred batch reactors by Kim and Vipulanandan (2006). Lead-contaminated water up to $100 \mathrm{mg} / \mathrm{L}$ and clay soil up to $3,000 \mathrm{mg} \mathrm{kg} / \mathrm{L}$ with the surfactant concentration up to 10 critical micelle concentration was used in this study. Of the surfactants used, biosurfactant produced from used vegetable oil had the best removal efficiency of $75 \%$ at a lead contamination of $100 \mathrm{mg} / \mathrm{L}$ in water at $\mathrm{pH}$ of over 12. The Fourier-transformed infrared spectroscopy study showed that the carboxyl group in the biosurfactant was effective in removing the lead from the solution. Mulligan et al. (2001) used batch washing experiments to evaluate the feasibility of using biosurfactants for the removal of heavy metals from sediments. Surfactin from Bacillus subtilis, rhamnolipids from Pseudomonas aeruginosa and sophorolipid from Torulopsis bombicola were evaluated in a metal-contaminated sediment $(110 \mathrm{mg} \mathrm{kg} / \mathrm{L}$ copper and 3,300 $\mathrm{mg} \mathrm{kg} / \mathrm{L}$ zinc). A single washing with $0.5 \%$ rhamnolipid removed $65 \%$ of the copper and $18 \%$ of the zinc, whereas $4 \%$ sophorolipid removed $25 \%$ of the copper and $60 \%$ of the zinc. Surfactin was less effective, removing $15 \%$ of the copper and $6 \%$ of the zinc (Mulligan et al. 2001). The biosurfactant produced by the isolate Pseudomonas aeruginosa $\mathrm{AB} 4$ has been shown to be responsible for the sequestration of $\mathrm{Cd}$ and $\mathrm{Pb}$, with 50 and $36 \%$ removal of lead and cadmium observed with $1 \% \mathrm{v} / \mathrm{v}$ rhamnolipid extract (Hazra et al. 2011). In a study by Chen et al. (2011), the biosurfactin; surfactin produced by Bacillus subtilis (BBK006) was found to be very effective for the separation of mercury species even at low concentrations when compared to chemical surfactants. Since biosurfactants can be used to remediate sites contaminated with chlorinated hydrocarbons and heavy metals separately, the development and use of biosurfactants for simultaneous removal of hydrocarbon and metal is a feasible option. 


\section{Phytoremediation}

Phytoremediation is a remediation technique that exploits the use of plants to remediate contaminated soils and water (Wu et al. 2012). Inorganic compounds are phytoremediated by the essential processes of phytostabilization and phytoextraction, while processes, such as phytotransformation/ phytodegradation, rhizofiltration, and rhizodegradation are commonly used to remediate organic contaminants (Tangahu et al. 2011). This technology can be considered advantageous in terms of it being economically feasible, environmentally friendly, energy efficient, can be applied to large areas and be carried out in situ with no secondary pollution (Srivastava et al. 2012; Sakakibara et al. 2011; Wu et al. 2012). However, a major limitation of phytoremediation is that a specified plant species characteristically remediates a very limited number of pollutants (Wu et al. 2012). Some factors that affect the effectiveness of phytoremediation are the plant root depth, level of contamination, the age of plant, the contaminant concentration and climatic condition (Tangahu et al. 2011). Metal reservoirs can exist in aquatic environments (Ndimele et al. 2009). Certain plants are known to be able to accumulate relatively large amounts of pollutants like heavy metals (Ravera et al. 2003). In a study to evaluate the plants Lemna minor and Azolla pinnata for heavy metal removal, A. pinnata was found to remove $96 \%$ of $\mathrm{Mn}, 97 \%$ of $\mathrm{Cu}, 98 \%$ of $\mathrm{Zn}, 70 \%$ of $\mathrm{Fe}$, $96 \%$ of $\mathrm{Pb}, 93 \%$ of $\mathrm{Cr}, 78 \%$ of $\mathrm{Cd}$, after 7 days and this was comparatively higher than the removal by $L$. minor which removed $94 \%$ of $\mathrm{Mn}, 86 \%$ of $\mathrm{Cu}, 62 \%$ of $\mathrm{Zn}, 74 \%$ of $\mathrm{Fe}, 84 \%$ of $\mathrm{Pb}, 63 \%$ of $\mathrm{Cr}, 78 \%$ of $\mathrm{Cd}$. The removal of copper from an aqueous solution by the aquatic plants, Centella asiatica and Eichhornia crassipes was evaluated by Mokhtar et al. (2011). The maximum removal of copper in the solutions containing $C$. asiatica was $99.6 \%$ as compared to $97.3 \%$ in solutions containing E. crassipes. E. crassipes was also found to phytoremediate significant amounts of $\mathrm{Hg}$ and methyl mercury ( $\mathrm{MeHg}$ ) from aqueous solution. The site of accumulation of $\mathrm{Hg}$ and $\mathrm{MeHg}$ was found preferentially in the roots with little translocation to the shoots or leaves of the plant. The ability of Eleocharis acicularis to hyperaccumulate $\mathrm{Cu}, \mathrm{Zn}$, As, and $\mathrm{Cd}$ under natural conditions was demonstrated by Sakakibara et al. (2011). The highest concentrations of heavy metals in the shoots of E. acicularis were $20,200 \mathrm{mg} \mathrm{Cu} / \mathrm{kg}, 14,200 \mathrm{mg}$ $\mathrm{Zn} / \mathrm{kg}, 1,740 \mathrm{mg} \mathrm{As} / \mathrm{kg}, 894 \mathrm{mg} \mathrm{Pb} / \mathrm{kg}$, and $239 \mathrm{mg} \mathrm{Cd} / \mathrm{kg}$. Phytoremediation has been frequently linked with inorganic compounds such as heavy metals (Wong 2003). However, there have been several published studies on the use of phytoremediation to degrade hydrocarbon compounds (Lee et al. 2008; Palmroth et al. 2002).

Phytoremediation has been proposed as an efficient, lowcost remediation technique to restore areas contaminated with chlorinated solvents. A review by Van Aken et al. (2010) focuses on recent advances in phytoremediation for the treatment of polychlorinated biphenyls. In a study by Nzengung et al. (1999), aquatic plants and freshwater algae were successful at removing chlorinated alkanes from water, with $>80 \%$ of the parent chemical sequestered, transformed, and/or assimilated by the biomass. The chlorinated insecticide Chlorpyrifos in solution was found to be taken up by the plants Populus sp. and Salix sp. Plant roots accumulated higher concentration of Chlorpyrifos than plant shoots. Chlorpyrifos was found to be further metabolized by the plant as it did not persist in plant tissue (Lee et al. 2012). Wang et al. (2011b) demonstrated that Cornus sericea grown in solution could be used in the remediation of tetrachloroethylene, trichloroethylene and 1,1,2-trichloroethane.

The ability of plants to remediate multiple contaminants both of an organic and inorganic nature, allows phytoremediation to be exploited for the remediation of environments co-contaminated with heavy metals and chlorinated compounds. However, little work has been done on heavy metal and chlorinated co-contaminated water. There are conversely studies on co-contaminated soil. Wu et al. (2012) revealed that that S. plumbizincicola intercropped with $M$. sativa together with liming was effective at remediating co-contaminated soil. They reported that a significant soil PCB degradation of up to $25.2 \%$ could be achieved if soil $\mathrm{pH}$ was adjusted to 5.56 combined with intercropping of $S$. plumbizincicola with $M$. sativa, in addition to the high removal rates of $\mathrm{Cd}, \mathrm{Cu}$. Phytoremediation potential of Helianthus annuus L. in sewage-irrigated indo-gangetic alluvial soils in India was investigated by Mani et al. (2012). The study indicated that $H$. annuus L. is highly sensitive to $\mathrm{Cr}$ and $\mathrm{Zn}$ in terms of metallic pollution. For $\mathrm{Cr}$-phytoremediation, humic acid treatment at $500 \mathrm{~mL} /$ acre hectare increased the phytoremediation potential of $H$. annuus $\mathrm{L}$. and induced 3.21 and $3.16 \mathrm{mg} / \mathrm{kg}$ of $\mathrm{Cr}$ accumulation in the roots and shoots, respectively. The authors recommend the use of this plant for the phytoremediation of $\mathrm{Cr}$ in the sewage-irrigated Gangetic alluvial soils.

\section{Conclusion}

Co-contamination of water with chlorinated organic compounds and metal pollutants is common and such sites are usually difficult to remediate because of the different treatment process required for the different classes of pollutants. Despite the frequent occurrences of co-contaminated sites, limited studies have been carried out to address this problem, which continue to pose serious environmental and health challenges because of the continued release of 
chlorinated organic compounds and heavy metals into the environment by many industries, refineries and mines. Although laboratory results indicate good potential of the various bioremediation options discussed in this review, extensive field studies are required to properly assess the feasibility and effectiveness of these approaches. Also, since the success of any of these remediation options could be site-specific, efforts should be made to develop a solution that can generally be applied to different sites. This could help to abate the problem of co-contamination commonly being encountered worldwide.

\section{References}

Abdel-Ghani NT, Hefny M, El-Chaghaby GAF (2007) Removal of lead from aqueous solution using low cost abundantly available adsorbents. Int. J. Environ. Sci. Tech. 4(1):67-73

Addagalla VA, Naif AD, Hilal N (2009) Study of various parameters in the biosorption of heavy metals on activated sludge. World Appl Sci J 5:32-40 (Special Issue for Environment)

Akporhonor EE, Egwaikhide PA (2007) Removal of selected metal ions from aqueous solution by adsorption onto chemically modified maize cobs. Sci Res Essays 2(4):132-134

Alshaebi FY, Yaacob WZW, Samsuldin AR (2009) Sorption on zero -valent iron (ZVI) for arsenic removal. Eur J Sci Res 33(2):214219

Ashraf MA, Wajid A, Mahmood K (2011) Low cost biosorbent banana peel (Musa sapientum) for the removal of heavy metals. Sci Res Essays 6(19):4055-4064

Azouaou N, Sadaoui Z, Mokaddem H (2008) Removal of cadmium from aqueous solution by adsorption on vegetable wastes. J Appl Sci 8(24):4638-4643

Baath E (1989) Effects of heavy-metals in soil on microbial processes and populations (a review). Water Air Soil Pollut 47(3-4): 335-379

Baldrian P, Der Wiesche CI, Gabriel J, Nerud F, Zadrazil F (2000) Influence of cadmium and mercury on activities of ligninolytic enzymes and degradation of polycyclic aromatic hydrocarbons by Pleurotus ostreatus in soil. Appl Environ Microbiol 66(6): 2471-2478

Balestrazzi A, Bonadei M, Quattrini E, Carbonera D (2009) Occurrence of multiple metal-resistance in bacterial isolates associated with transgenic white poplars (Populus alba L.). Ann Micro 59(1):17-23

Barkay T, Miller SM, Summers AO (2003) Bacterial mercury resistance from atoms to ecosystems. FEMS Microbiol Rev 27(2-3):355-384

Bhatnagar A, Vilar VJP, Botelho CMS, Boaventura RAR (2010) Coconut-based biosorbents for water treatment-a review of the recent literature. Adv Colloid Interface Sci 160:1-15

Boparai HK, Joseph M, O'Carroll DM (2011) Kinetics and thermodynamics of cadmium ion removal by adsorption onto nano zerovalent iron particles. J Hazard Mater 186(1):458-465

Borsetti F, Francia F, Turner RJ, Zannoni D (2007) The thioldisulfide oxidoreductase DsbB mediates the oxidizing effects of the toxic metalloid tellurite $\left(\mathrm{TeO}_{3}{ }^{2-}\right)$ on the plasma membrane redox system of the facultative phototroph Rhodobacter capsulatus. J Bacteriol 189(3):851-859

Boving TB, McCray JE (2000) Cyclodextrin-enhanced remediation of organic and metal contaminants in porous media and groundwater. Remed J 10(2):59-83
Bruins MR, Kapil S, Oehme FW (2000) Microbial resistance to metals in the environment. Ecotoxicol Environ Saf 45(3):198207

Brusseau ML, Wang X, Wang W (1997) Simultaneous elution of heavy metals and organic compounds from soil by cyclodextrin. Environ Sci Tech 31(4):1087-1092

Cathum SJ, Boudreau A, Obenauf A, Dumouchel A, Brown CE, Punt M (2006) Treatment of mixed contamination in water using cyclodextrin-based materials. Remed J 16(4):43-56

Cervantes C, Espino-Saldaña AE, Acevedo-Aguilar F, León-Rodriguez IL, Rivera-Cano ME, Avila-Rodríguez M, WróbelKaczmarczyk K, Wróbel-Zasada K, Gutiérrez-Corona JF, Rodríguez-Zavala JS, Moreno-Sánchez R (2006) Microbial interactions with heavy metals. Rev Latinoam Microbiol 48(2): 203-210

Chatain V, Hanna K, Brauer C, Bayard R, Germain P (2004) Enhanced solubilization of arsenic and 2,3,4,6 tetrachlorophenol from soils by a cyclodextrin derivative. Chemosphere 57(3):197-206

Chen H, Chen C, Reddy AS, Chen C, Li WR, Tseng M, Liu H, Pan W, Maity JP, Atla SB (2011) Removal of mercury by foam fractionation using surfactin, a biosurfactant. Int $\mathrm{J}$ Mol Sci 12(11):8245-8258

Cheng IF, Fernando Q, Korte N (1997) Electrochemical dechlorination of 4-chlorophenol to phenol. Environ Sci Tech 31(4):10741078

Crannell BS, Eighmy TT, Krzanowski JE, Eusden JD Jr, Shaw EL, Francis CA (2000) Heavy metal stabilization in municipal solid waste combustion bottom ash using soluble phosphate. Waste Manag 20(2-3):135-148

Dahrazma B, Mulligan CN (2007) Investigation of the removal of heavy metals from sediments using rhamnolipid in a continuous flow configuration. Chemosphere 69(5):705-711

Davis ME, Brewster ME (2004) Cyclodextrin-based pharmaceutics: past, present and future. Nat Rev Drug Discov 3(12):1023-1035

Del Valle EMM (2004) Cyclodextrins and their uses: a review. Process Biochem 39(9):1033-1046

Deng N, Luo F, Wu F, Xiao M, Wum X (2000) Discoloration of aqueous reactive dye solutions in the $\mathrm{UV} / \mathrm{Fe}^{0}$ system. Water Res 34(8):2408-2411

Doong RA, Lee CC, Chen KT, Wu SF (2004) Coupled reduction of chlorinated hydrocarbons and heavy metals by zerovalent silicon. Water Sci Technol 50(8):89-96

Dries J, Bastiaens L, Springael D, Kuypers S, Agathos SN, Diels L (2005) Effect of humic acids on heavy metal removal by zerovalent iron in batch and continuous flow column systems. Water Res 39(15):3531-3540

Ehsan S, Prasher SO, Marshall WD (2007) Simultaneous mobilization of heavy metals and polychlorinated biphenyl (PCB) compounds from soil with cyclodextrin and EDTA in admixture. Chemosphere 68(1):150-158

Fernandes VC, Albergaria JT, Oliva-Teles T, Delerue-Matos C, De-Marco P (2009) Dual augmentation for aerobic bioremediation of MTBE and TCE pollution in heavy metal-contaminated soil. Biodegradation 20(3):375-382

Field JA, Sierra-Alvarez R (2004) Biodegradability of chlorinated solvents and related chlorinated aliphatic compounds. Rev Environ Sci Biotechnol 3(3):185-254

Fierens S, Mairess H, Heilier JF, De Burbure C, Focant JF, Eppe G, De Pauw E (2003) Dioxin/polychlorinated biphenyl body burden, diabetes and endometriosis: findings in a populationbased study in Belgium. Biomarkers 8(6):529-534

Foulkes EC (1998) Biological membranes in toxicology. Taylor \& Francis, Philadelphia

Franke S, Grass G, Rensing C, Nies DH (2003) Molecular analysis of the copper transporting efflux system CusCFBA of Escherichia coli. J Bacteriol 185(13):3804-3812 
Geslin C, Llanos J, Prieur D, Jeanthon C (2001) The manganese and iron superoxide dismutases protect Escherichia coli from heavy metal toxicity. Res Microbiol 152(10):901-905

Gheju M (2011) Hexavalent chromium reduction with zero-valent iron (ZVI) in aquatic systems. Water Air Soil Pollut 222(1-4):103-148

Gibb C, Satapanajaru T, Comfort SD, Shea PJ (2004) Remediating dicamba-contaminated water with zerovalent iron. Chemosphere 54(7):841-848

Gonen F, Serin DS (2012) Adsorption study on orange peel: removal of $\mathrm{Ni}(\mathrm{II})$ ions from aqueous solution. Afr J Biotech 11(5):1250 1258

Gotpagar J, Grulke E, Tsang T, Bhattacharyya D (2007) Reductive dehalogenation of trichloroethylene using zero-valent iron. Environ Progr 16(2):137-143

Goulhen F, Gloter A, Guyot F, Bruschi M (2006) Cr(VI) detoxification by Desulfovibrio vulgaris strain Hildenborough: microbemetal interactions studies. Appl Microbiol Biotech 7(6):892-897

Grass G, Fan B, Rosen BP, Franke S, Nies DH, Rensing C (2001) ZitB (YbgR), a member of the cation diffusion facilitator family, is an additional zinc transporter in Escherichia coli. J Bacteriol 183(15):4664-4667

Gribble GW (1996) The diversity of natural organochlorines in living organisms. Pure Appl Chem 68(9):1699-1712

Grittini C, Malcomson M, Fernando Q, Korte N (1995) Rapid dechlorination of polychlorinated biphenyls on the surface of a Pd/Fe bimetallic system. Environ Sci Tech 29(11):2898-2900

Gunawardana B, Singhal N, Swedlund P (2011) Degradation of chlorinated phenols by zero valent iron and bimetals of iron: a review. Environ Eng Res 16(4):187-203

Hanberg A (1996) Toxicology of environmentally persistent chlorinated organic compounds. Pure Appl Chem 68(9):1791-1799

Hardy LI, Gillham RW (1996) Formation of hydrocarbons from the reduction of aqueous $\mathrm{CO}_{2}$ by zero-valent iron. Environ Sci Tech 30(1):57-65

Hazra C, Kundu D, Ghosh P, Joshi D, Dandia N, Chaudharia A (2011) Screening and identification of Pseudomonas aeruginosa AB4 for improved production, characterization and application of a glycolipid biosurfactant using low-cost agro-based raw materials. J Chem Technol Biotechnol 86(2):185-198

Herman DC, Artiola JF, Miller RM (1995) Removal of cadmium, lead, and zinc from soil by a rhamnolipid biosurfactant. Environ Sci Tech 29(9):2280-2285

Hileman B (1993) Concerns broaden over chlorine and chlorinated hydrocarbons. Chem Eng News 71(16):11-20

Hocheolsong E, Carraway R (2005) Reduction of chlorinated ethanes by nanosized zero-valent iron: kinetics, pathways, and effects of reaction conditions. Environ Sci Tech 39(16):6237-6245

Hughes MN, Poole RK (1991) Metal speciation and microbial growth-the hard (and soft) facts. J Gen Microbiol 137(4):725734

Igwe JC, Abia AA (2005) Sorption kinetics and intraparticulate diffusivities of $\mathrm{Cd}, \mathrm{Pb}$ and $\mathrm{Zn}$ ions on maize $\mathrm{cob}, \mathrm{Pb}$ and $\mathrm{Zn}$ ions on maize cob. Afr J Biotech 4(6):509-512

Igwe JC, Abia AA (2007) Studies on the effects of temperature and particle size on bioremediation of AS (III) from aqueous solution using modified and unmodified coconut fiber. Glob J Environ Res 1(1):22-26

Igwe JC, Nwokennayal EC, Abia AA (2005) The role of pH in heavy metal detoxification by biosorption from aqueous solutions containing chelating agents. Afr J Biotechol 4(10):1109-1112

Imagawa A, Seto R, Nagaosa Y (2000) Adsorption of chlorinated hydrocarbons from air and aqueous solutions by carbonized rice husk. Carbon 38(4):623-641

Inoaoka T, Matsumura Y, Tsuchido T (1999) SodA and manganese are essential for resistance to oxidative stress in growing and sporulating cells of Bacillus subtillis. J Bacteriol 181(6):19391943

Janda V, Vasek P, Bizova J, Belohlav Z (2004) Kinetic models for volatile chlorinated hydrocarbons removal by zero-valent iron. Chemosphere 54(7):917-925

Järup L (2003) Hazards of heavy metal contamination. Br Med Bull 68(1):167-182

Jeffrey WW, Silver S (1984) Bacterial resistance and detoxification of heavy metals. Enzym Microb Tech 6(12):530-537

Ji G, Silver S (1995) Bacterial resistance mechanism for heavy metals of environmental concern. J Ind Microbiol 14(2):61-75

Junyapoon S (2005) Use of zero-valent iron for wastewater treatment. KMITL Sci Tech J 5(3):587-595

Khan MN, Wahab MF (2007) Characterization of chemically modified corncobs and its application in the removal of metal ions from aqueous solution. J Hazard Mater 14(1):237-244

Kim Y, Carraway ER (2000) Dechlorination of pentachlorophenol by zero valent iron and modified Zero valent irons. Environ Sci Tech 34(10):2014-2017

Kim J, Vipulanandan C (2006) Removal of lead from contaminated water and clay soil using a biosurfactant. J Environ Eng 132(7): $777-786$

Kong IC (1998) Metal toxicity on the dechlorination of monochlorophenols in fresh and acclimated anaerobic sediment slurries. Water Sci Technol 38(7):143-150

Kumar U, Bandyopadhyay M (2006) Sorption of cadmium from aqueous solution using pretreated rice husk. Bioresour Technol 97(1):104-109

Kuo C, Genthner BRS (1996) Effect of added heavy metal ions on biotransformation and biodegradation of 2-chlorophenol and 3 -chlorobenzoate in anaerobic bacterial consortia. Appl Environ Microbiol 62(7):2317-2323

Lasheen MR, Ammar NS, Ibrahim HS (2012) Adsorption/desorption of $\mathrm{Cd}(\mathrm{II}), \mathrm{Cu}(\mathrm{II})$ and $\mathrm{Pb}(\mathrm{II})$ using chemically modified orange peel: equilibrium and kinetic studies. Solid State Sci 14(2):202-210

Lee T, Lim H, Lee Y, Park JW (2003) Use of waste iron metal for removal of $\mathrm{Cr}(\mathrm{VI})$ from water. Chemosphere 53(5):479-485

Lee W, Wood TK, Chen W (2006) Engineering TCE-degrading Rhizobacteria for heavy metal accumulation and enhanced TCE degradation. Biotechnol Bioeng 95(3):399-403

Lee SH, Lee WS, Lee CH, Kim JG (2008) Degradation of phenanthrene and pyrene in rhizosphere of grasses and legumes. J Hazard Mater 153:892-898

Lee KY, Strand SE, Doty SL (2012) Phytoremediation of Chlorpyrifos by Populus and Salix. Inter J Phytoremediation 14(1):48-61

Lehr JH, Hyman M, Gass TE, Seevers WJ (2001) Handbook of complex environmental remediation problems. McGraw-Hill, New York

Lesmana SO, Febriana N, Soetaredjo FE, Sunarso J, Ismadji S (2009) Studies on potential applications of biomass for the separation of heavy metals from water and wastewater. Biochem Eng J 44(1):19-41

Li XQ, Zhang WX (2007) Sequestration of metal cations with zerovalent iron nanoparticles-a study ith high resolution X-Ray photoelectron spectroscopy (Hr-Xps). J Phys Chem 111(19): 6939-6946

Li Z, Tang Y, Cao X, Lu D, Luo F, Shao W (2008) Preparation and evaluation of orange peel cellulose adsorbents for effective removal of cadmium, zinc, cobalt and nickel. Colloids Surf A Physicochem Eng Asp 317(1-3):512-521

Lien H, Jhuo Y, Chen L (2007) Effect of heavy metals on dechlorination of carbon tetrachloride by iron nanoparticles. Environ Eng Sci 24(1):21-30

Lin CJ, Lo SL, Liou YH (2004) Dechlorination of trichloroethylene in aqueous solution by noble metal-modified iron. J Hazard Mater 116(3):219-228 
Lohmeier-Vogel EM, Ung S, Turner RJ (2004) In vivo P nuclear magnetic resonance investigation of tellurite toxicity in Escherichia coli. Appl Environ Microbiol 70(12):7342-7347

Lookman R, Bastiaens L, Borremans B, Maesen M, Gemoets J, Diels L (2004) Batch-test study on the dechlorination of 1,1,1trichloroethane in contaminated aquifer material by zero-valent iron. J Contam Hydrol 74(1-4):133-144

Mahvi AH, Diels L (2004) Biological removal of cadmium by Alcaligenes eutrophus CH34. Int J Environ Sci Tech 1(3):199204

Mani D, Sharma B, Kumar C, Pathak N, Balak S (2012) Phytoremediation potential of Helianthus annuus $L$ in sewage-irrigated indo-gangetic alluvial soils. Int J Phytoremediation 14:235-246

Matheson LJ, Tratnyek PG (1994) Reductive dehalogenation of chlorinated methanes by iron metal. Environ Sci Technol 28(12):2045-2053

McEntee JD, Woodrow JR, Quirk AV (1986) Investigation of cadmium resistance in Alcaligenes sp. Appl Environ Microbiol 51(3):515-520

Mergeay M (1991) Towards an understanding of the genetics of bacterial metal resistance. Trends Biotechnol 9(1):17-24

Misra TK (1992) Bacterial resistance to inorganic mercury salts and organomercurials. Plasmid 27(1):4-16

Mokhtar H, Morad N, Fizri FFA (2011) Phytoaccumulation of copper from aqueous solutions using Eichhornia crassipes and Centella asiatica. Int J Environ Sci Dev 2(3):205-210

Mrozik A, Piotrowska-Seget Z (2010) Bioaugmentation as a strategy for cleaning up of soils contaminated with aromatic compounds. Microbiol Res 165(5):363-375

Mulligan CN, Wang S (2006) Remediation of a heavy metalcontaminated soil by a rhamnolipid foam. Eng Geol 85(1-2): $75-81$

Mulligan CN, Yong RN, Gibbs BF (2001) Heavy metal removal from sediments by biosurfactants. J Hazard Mater 85(1-2):111-125

Murthy CVR, Ramesh P, Ramesh A (2011) Study of biosorption of $\mathrm{Cu}$ (II) from aqueous solutions by coconut shell powder. Chem Sci J CSJ-17

Namasivayam C, Kavitha D (2006) IR, XRD and SEM studies on the mechanism of adsorption of dyes and phenols by coir pith carbon from aqueous phase. Microchem J 82(1):43-48

Ndimele PE, Jenyo-Oni A, Jibuike CC (2009) The levels of lead (Pb) in water, sediment and a commercially important fish species (Chrysichthys nigrodigitatus) (Lacepede, 1803) from Ologe Lagoon, Lagos. Nigeria. J Environ Ext 8:70-75

Nieboer M, Vis AJ, Witholt B (1996) Overproduction of a foreign membrane protein in Escherichia coli stimulates and depends on phospholipid synthesis. Eur J Biochem 241(2):691-696

Nies DH (2000) Heavy metal-resistant bacteria as extremophiles: molecular physiology and biotechnological use of Ralstonia sp. CH34. Extremophiles 4(2):77-82

Nies DH (2003) Efflux-mediated heavy metal resistance in prokaryotes. FEMS Microbiol Rev 27(2-3):313-339

Ning-chuan F, Xue-yi G, Sha L (2010) Enhanced Cu(II) adsorption by orange peel modified with sodium hydroxide. Trans Nonferrous Met Soc China 20(12):146-152

Nzengung VA, Wolfe LN, Rennels DE, McCutcheon SC, Wang C (1999) Use of aquatic plants and algae for decontamination of waters polluted with chlorinated alkanes. Int J Phytoremediation 1(3):203-226

Palmroth MRT, Pichtel J, Puhakka JA (2002) Phytoremediation of subarctic soil contaminated with diesel fuel. Bioresour Technol 84(3):221-228

Pardue JH, Kongara S, Jones WJ (1996) Effect of cadmium on reductive dechlorination of trichloroaniline. Environ Toxicol Chem 15(7):1083-1088
Pomposiello PJ, Demple B (2002) Global adjustment of microbial physiology during free radical stress. Adv Microb Physiol 46:319-341

Puls RW, Paul CJ, Powell RM (1999) The application of in situ permeable reactive (zero-valent iron) barrier technology for the remediation of chromate contaminated groundwater: a field test. Appl Geochem 14(8):989-1000

Rasmussen LD, Sorensen SJ, Turner RR, Barkay T (2000) Application of a merlux biosensor for estimating bioavailable mercury in soil. Soil Biol Biochem 32(5):639-649

Ravera O, Cenci R, Beon GM, Dantas M, Lodigiani P (2003) Trace element concentrations in freshwater mussels and macrophytes as related to those in their environment. J Limnol 62(1):61-70

Roane TM, Josephson KL, Pepper IL (2001) Dual-bioaugmentation strategy to enhance remediation of cocontaminated soil. Appl Environ Microbiol 67(7):3208-3215

Rouch DA, Lee BTD, Morby AP (1995) Understanding cellular responses to toxic agents: a model for mechanism choice in bacterial metal resistance. J Ind Microbiol 14(2):132-141

Sag Y, Kutsal T (2000) Determination of the biosorption activation energies of heavy metal ions on Zoogloea ramigera and Rhizopus arrhizus. Process Biochem 35(8):801-807

Said WA, Lewis DL (1991) Quantitative assessment of the effects of metals on microbial degradation of organic chemicals. Appl Environ Microbiol 57(5):1498-1503

Sakakibara M, Ohmori Y, Ha NTH, Sano S, Sera K (2011) Phytoremediation of heavy metal-contaminated water and sediment by Eleocharis acicularis. Clean Soil Air Water 39(8):735741

Sandrin TR, Maier RM (2003) Impact of metals on the biodegradation of organic pollutants. Environ Health Perspect 111(8):10931101

Sandrin TR, Chech AM, Maier RM (2000) A rhamnolipid biosurfactant reduces cadmium toxicity during biodegradation of naphthalene. Appl Environ Microbiol 66(10):4585-4588

Sar A, Tuzen M (2008) Biosorption of total chromium from aqueous solution by red algae (Ceramium virgatum): equilibrium, kinetic and thermodynamic studies. J Hazard Mater 160(2-3):349-355

Say R, Denizli A, Aroca MY (2001) Biosorption of cadmium (II), lead (II) and copper(II) with the filamentous fungus Phanerochaete chrysosporium. Bioresour Technol 76(1):67-70

Scherer J, Nies DH (2009) CzcP is a novel efflux system contributing to transition metal resistance in Cupriavidus metallidurans CH34. Mol Microbiol 73(4):601-621

Schiewer S, Balaria A (2009) Biosorption of $\mathrm{Pb}^{2+}$ by original and protonated citrus peels: equilibrium, kinetics, and mechanism. Chem Eng J 146(2):211-219

Schiewer S, Patil SB (2008) Pectin-rich fruit wastes as biosorbents for heavy metal removal: equilibrium and kinetics. Bioresour Technol 99(6):1896-1903

Scott JA, Palmer SJ (1990) Sites of cadmium uptake in bacteria used for biosorption. Appl Environ Microbiol 33(2):221-225

Shao-ping T, Hong W, Chun-an M, Wei-ping L (2005) Rapid dechlorination of chlorinated organic compounds by nickel/iron bimetallic system in water. J Zhejiang Univ Sci 6A(7):627-631

Shirdam R, Khanafari A, Tabatabaee A (2006) Cadmium, nickel and vanadium accumulation by three strains of marine bacteria. Iran J Biotechnol 4(3):180-187

Shokes TE, Moller G (1999) Removal of dissolved heavy metals from acid rock drainage using iron metal. Environ Sci Technol 33(2):282-287

Silver S (1996) Bacterial resistances to toxic metal ions-a review. Gene 179(1):9-19

Silver S, Phung LT (1996) Bacterial heavy metal resistance: new surprises. Annu Rev Microbiol 50:753-789 
Skold EM, Thyne GD, Drexler JW, McCray JE (2007) Determining conditional stability constants for $\mathrm{Pb}$ complexation by carboxymethyl- $\beta$-cyclodextrin (CMCD). J Contam Hydrol 93(1-4):203215

Skold EM, Thyne GD, Drexler JW, McCray JE (2009) Solubility enhancement of seven metal contaminants using carboxymethyl$\beta$-cyclodextrin (CMCD). J Contam Hydrol 107(3-4):108-113

Springael D, Diels L, Hooyberghs L, Kreps S, Mergeay M (1993) Construction and characterization of heavy metal-resistant haloaromatic-degrading Alcaligenes eutrophus Strains. Appl Environ Microbiol 59(1):334-339

Srivastava S, Suprasanna P, D'Souza SF (2012) Mechanisms of arsenic tolerance and detoxification in plants and their application in transgenic technology: a critical appraisal. Int J Phytoremediation 14(5):506-517

Stohs SJ, Bagchi D (1995) Oxidative mechanisms in the toxicity of metal ions. Free Radic. Biol. Med. 18(2):321-336

Sud D, Mahajan G, Kaur MP (2008) Agricultural waste material as potential adsorbent for sequestering heavy metal ions from aqueous solutions-a review. Bioresour Technol 99(14):60176027

Surchi KMS (2011) Agricultural wastes as low cost adsorbents for $\mathrm{Pb}$ removal: kinetics, equilibrium and thermodynamics. Int $\mathrm{J}$ Chem 3(3): 103-112

Tangahu BV, Abdullah SRS, Basri H, Idris M, Anuar N, Mukhlisin M (2011) A Review on heavy metals (As, $\mathrm{Pb}$, and $\mathrm{Hg}$ ) uptake by plants through phytoremediation. Int J Chem Eng 2011. Article ID 939161

Tick GR, Lourenso F, Lynnwood A, Brusseau ML (2003) Pilot-scale demonstration of cyclodextrin as a solubility-enhancement agent for remediation of a tetrachloroethene-contaminated aquifer. Environ Sci Technol 37(24):5829-5834

Truex MJ, Vermeul VR, Mendoza DP, Fritz BG, Mackley RD, Oostrom M, Wietsma TW, Macbeth TW (2011) Injection of zero-valent iron into an unconfined aquifer using shear-thinning fluids. Ground Water Monit. Remediat. 31(1):50-58

Tsutomu S, Kobayashi Y (1998) The ars operon in the skin element of Bacillus subtilis confers resistance to arsenate and arsenite. J Bacteriol 180(7):1655-1661

Turner RJ, Aharonowitz Y, Weiner J, Taylor DE (2001) Glutathione is a target of tellurite toxicity and is protected by tellurite resistance determinants in Escherichia coli. Can J Microbiol 47(1):33-40

US Department of Defense (2004) Cyclodextrin-enhanced in situ removal of organic contaminants from groundwater at department of defense sites. Environmental Security Technology Certification Program

Uysal A, Turkman A (2005) Effect of biosurfactant on 2,4-dichlorophenol biodegradation in an activated sludge bioreactor. Process Biochem 40(8):2745-2749
Van Aken B, Correa PA, Schnoor JL (2010) Phytoremediation of polychlorinated biphenyls: new trends and promises. Environ Sci Technol 44:2767-2776

Vasudevan P, Padmavathy V, Dhingra SC (2003) Kinetics of biosorption of cadmium on Baker's yeast. Bioresour Technol 89(3):281-287

Volesky B, May-Phillips HA (1995) Biosorption of heavy metals by Saccharomyces cerevisiae. Appl Microbiol Biotechnol 42(5): 797-806

Wan C, Chen YH, Wei R (1998) Dechlorination of chloromethanes on iron and palladium-iron bimetallic surface in aqueous systems. Environ Toxicol Chem 18(6):1091-1096

Wang X, Brusseau ML (1995) Simultaneous complexation of organic compounds and heavy metals by a modified cyclodextrin. Environ Sci Technol 29(10):2632-2635

Wang Y, Zhou D, Wang Y, Zhu X, Jin S (2011a) Humic acid and metal ions accelerating the dechlorination of 4-chlorobiphenyl by nanoscale zero-valent iron. J Environ Sci 23(8):1286-1292

Wang C, Ma X, Walsh MP (2011b) Competitive uptake and phytomonitoring of chlorinated contaminant mixtures by Redosier Dogwood (Cornus sericea). Int $\mathrm{J}$ Phytoremediation 13(4):333-344

Wanga G, Zhoua Y, Wanga X, Chaia X, Huanga L, Dengb N (2010) Simultaneous removal of phenanthrene and lead from artificially contaminated soils with glycine- $\beta$ - cyclodextrin. J Hazard Mater 184(1-3):690-695

Wireman J, Liebert CA, Smith T, Summers OA (1997) Population biology of the mercury resistance (mer) operon in the facultative Gram negative enteric flora of humans and other primates. Appl Environ Microbiol 63:4494-4503

Wong MH (2003) Ecological restoration of mine degraded soils, with emphasis on metal contaminated soils. Chemosphere 50(6):775780

Worden CR (2008) Effect of $\mathrm{pH}$ on cadmium toxicity and Associated gene expression in Escherichia coli. Masters thesis. The University of Wisconsin Oshkosh, Oshkosh

Wu L, Li Z, Han C, Liu L, Teng Y, Sun X, Pan C, Huang Y, Luo Y, Christie P (2012) Phytoremediation of soil contaminated with cadmium, copper and polychlorinated biphenyls. Int. J. Phytoremediation. 14(6):570-584

Yang C, Zeng Q, Wang Y, Liao B, Sun J, Shi H, Chen X (2010) Simultaneous elution of polycyclic aromatic hydrocarbons and heavy metals from contaminated soil by two amino acids derived from $\beta$-cyclodextrins. J Environ Sci 22(12):1910-1915

Zannoni D, Borsetti F, Harrison JJ, Turner RJ (2007) The bacterial response to the chalcogen metalloids Se and Te. Adv Microb Physiol 53:1-71 